\title{
EVOLUTION OF SOME EGYPTIAN STRAINS BARLEY CULTIVATORS FOR GREEN FODDER HYDROPONIC SYSTEM AND PREDICTION DIGESTIBILITY VALUES BY IN-VITRO DAISY II INCUBATOR
}

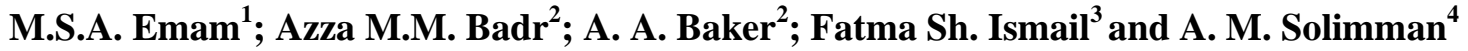 \\ ${ }^{1}$ Central Laboratory for Agricultural Climate, Agricultural Research Centre, Giza, Egypt. \\ ${ }^{2}$ Regional Center for Food and feed, Agric. Res. Centre., Giza, Egypt. \\ ${ }^{3}$ Department of Forage Crops Research, Field Crops Research Institute, Cairo, Egyp \\ ${ }^{4}$ Animal Nutrition department, Animal Production Research Institute, Agricultural Research Centre, \\ Giza, Egypt. \\ Email: mohamedsaad2005@yahoo.com.6 MichailBakhoumst. Dokki-Giza- Egypt. Postal code: \\ 12411P.O Box. 296 Imbaba.
}

(Received 8/7/2018, accepted $21 / 82018$ )

\section{SUMMARY}

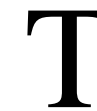

The hydroponic under Egyptian condition take more attention in the last decade. The experiment was conducted under net house in intensive hydroponic system and replicated three times during January and February 2017. The study was done to evaluate vegetative characteristics and quality properties of produced sprouting of six barley cultivars (Giza123,126,127,128,129 and130). The results observed that the sprouting can be produce in 8 days from planting to harvest using hydroponic technique under the net house conditions. The Highest green barley fodder was recorded with Giza 127 followed by 129 which gave 6.98, $6.83 \mathrm{Kg}$, respectively compared with other strain. The results indicated that the highest value of fresh sprout: seeds weight ratio was recorded significantly by Giza 127 followed by Giza 129 compared to the other four cultivars. The crude protein values in several green fodder barley species significant $(\mathrm{P}<0.05)$ increase $($ the range from 11.56 to $13.45 \%$ ) compared with its grains (the range from 9.58 to $12.60 \%$ ). The highest values $\mathrm{CP} \%$ in green fodder barley recorded with (Giza 127) was (13.45\% on DM basis). There were a significantly $(\mathrm{P}<0.05)$ increase for $\mathrm{CF} \%$ between green fodder barley species (the range from 9.93 to 14.36$)$ in 8 - days sprouting compared with the several original barley grains (the range from 5.67 to $8.85 \%$ ). Also, the EE were significant increased except (Giza 129 and Giza 130) were decreased. The highest significant values NDF was recorded (37.47\%) with (Giza 123) compared several cultivator Green fodder barley species, but ADF was recorded (17.93) with (Giza 127). The highest significant values ADF and acid insoluble ash were recorded (5.91 and 1.78) with (Giza 130) compared several cultivator Green fodder barley species. The highest significant values hemicellulose was recorded (20.85\%) with (Giza 123), celluloses was recorded (12.63\%) with (Giza 126) compared several cultivator Green fodder barley species. however, significant increased NDF-cell soluble was recorded (80.88) with (Giza 130). The parameters of nutritive values are predication from chemical composition observed significant increase of DCP between seed barley and several cultivator Green fodder barleys except Giza (129) and (130). The highest result values of DCP cultivator Green fodder barley was recorded with (Giza127) the value increase from $7.67 \%$ in seed to $8.44 \%$ in sprouting. The DDM and DMI were significantly decrease in all several cultivator Green fodder barleys compared with seed barley. Also, several cultivator Green fodder barley productions observed significantly decreased of TDN in all strains compared with its seeds. The parameters of energy values are predication from chemical composition of Egyptian barley for seed (Giza 128, Giza 127, Giza 130, Giza 129, Giza 126, and Giza 123) and it green fodder production observed significantly decreased of GE, NEL, NEM, NEg, DE and ME in all strains barely green fodder production compared with its seeds. Except the highest result prediction growth energy were recorded with seed Giza (129) compared with other barley strains, the values increase from 1.58 to 1.6 (MJ/Kg DM). Apparent dry matter and true dry matter digestibility by determination In-Vitro DaisyII incubator. The values in all several barleys green fodder was significant increase compared with its seeds. The highest values of seed barley were recorded with strain (Giza129) compared with other seed strains. Also, the best significant $(\mathrm{P}<0.05)$ values of data barley for green fodder production recorded with strains (Giza 129) compared with other strains (Giza 128, Giza 127, Giza 130, Giza 126, and Giza 123). Finally, the best significant $(\mathrm{P}<0.05)$ values of apparent dry matter and true dry matter digestibility of green fodder production was observed with strains (Giza129). The obtained results indicated that the highest values of economic production and profit were gained by Giza 127 and Giza 129 which gave 39.8 and 38.3LE/m2, 7.1 and 7.0 respectively with constant of other production costs. Conclusion This process takes place in a very versatile and intensive hydroponic growing unit, where only 
water and nutrients are used to produce a grass and root combination that is very highest values in nutrients, in physical characteristics, in digestibility analysis, high in protein and production costs. The best result recorded with Sprouted barley yield using Egyptian barley Giza 129 barely cultivar could be used animal's diets as hydroponic green forage in short period ( 8 days -3.5 production cycles /month) any time from year. Under the conditions of this experiment, the fodder strains (Giza 129) best results indicated could be used animal's diets. These feeds are suitable for use at all types and categories of animals.

Keywords: hydroponic system, barley seeds, sprouting, In-Vitro Daisy incubator, prediction energy and digestibility values.

\section{INTRODUCTION}

One of the important modern techniques for better water use efficiency (WUE) as well as for fodder production is using hydroponic culture. Hydroponic fodder is a technique of growing seeds of crops such as barley, cowpea, sorghum, wheat, maize or etc. in a hygienic environment free of chemicals i.e. insecticides, herbicides, fungicides and artificial growth promoters (Jensen and Malter, 1995 and Al-Hashmi, 2008).The produced green fodder is extremely high in protein and metabolic energy, which is highly digestible by domesticated animals (Caderand Bill, 2002; Rajendra el al., 1998 and Tudor et al., 2003). Barley considers an imperative crude material for feed industry and generally utilized for creature sustaining as grain in domesticated animals (Y1lmaz, 2007).

Research on hydroponically sprouted barley has shown an increase in fresh weight over the sprouting duration as well as changes in dry matter compared to dry seeds (Peer and Leeson 1985aand Trubey et al., 1969). The gain in fresh weight has been mainly attributed to imbibition's of water constituting up to 80-90\% of the fresh weight (Sneath and McIntosh, 2003). The sprouting of barley under net house system recorded the higher values of chemical analysis compared to sprouting under control cooling room. The economic benefits is considered when comparing the high cost of control cooling room and energy needs with the net cover system (El-Morsyet et al., 2013). Germination and sprouting activates enzymes that change the starch, protein, and lipids of the grain into simpler forms, for example, starch changes to sugars.

The whole product is then fed to the animals and the empty space in the chamber is used to germinate a new set of seeds (Mukhopad, 1994 and Cuddeford, 1989). All these special features of hydroponic culture make this methodology as one of the most important agricultural techniques in use for green forage production in many countries.

Chung et.al.(1989) found that in 5-day sprouts the fiber content was increased from $3.7 \%$ in un-sprouted barley seed to $6.0 \%$. Traditional in vivo methods of determining digestibility are cost-prohibitive and timeconsuming. As a result, In-vitro methods of determining digestibility have been developed for some species. Much of this work has been done in ruminant species and has provided estimates highly correlated to In-vivo digestibility values (Goldman et. al., 1987andStern et al., 1997). The in vitro procedure developed by Tilley and Terry (1963)has long been regarded as an accurate In-vitro method for predicting diet digestibility (Goldman et al., 1987 and Stern et al., 1997).Recently, a more efficient alternative to the Tilley and Terry (1963)method has been developed using the Ankom Daisy ${ }^{\mathrm{II}}$ incubator (Ankom Technology Corp., Fairport, NY). Wilman and Adesogan (2000) compared the two methods and found the Daisy ${ }^{\mathrm{II}}$ system provided slightly less accurate prediction of ruminant In-vitro digestibility. Lattimer et al., (2007) reported that the Daisy ${ }^{\mathrm{II}}$ could be used to predict valid estimates of DM digestibility (DMD) of high quality diets. Peer and Leeson1985a found significant losses in dry matter digestibility, which declined progressively during 7 to 8 day growing period nevertheless the digestibility of 4-day old sprouts barley was superior to original grain. However, according to Mansbridge and Gooch, 1985In-vitro digestibility of sprouts grown at 6 or 8 days ranged $72-74$ percent that was not significantly different.

Agriculture is the most critical sector in term of the global climate change. Natural water resources are affected by global climate change so food production and sustainability are endangered (Falkenmark, 2007). It's expected that the global climate change cause negative impact on the grazing lands in arid and semi-arid regions (Hoffman and Vogel, 2008). The rain fall is reduced while environmental temperature is increased, so the grassland yields decrease and range and meadow deteriorated over the time. Agriculture is the most critical sector in term of the global climate change. Natural water resources are affected by global climate change so food production and sustainability are 
endangered (Falkenmark, 2007). It's expected that the global climate change cause negative impact on the grazing lands in arid and semi-arid regions (Hoffman and Vogel, 2008). The rain fall is reduced while environmental temperature is increased, so the grassland yields decrease and range and meadow deteriorated over the time.

The analysis is expressed on an as received and on $100 \%$ dry matter basis. Nutrient calculated by equations are expressed on this basis represent the nutrient content of the feed when it was received at the lab. There are several values that can be calculated from these lab measurements. A number of equations have been used to estimate digestibility and energy values of forages. According to N.R.C., (2001)total digestible nutrient (TDN) is calculated from ADF, estimates the energy in a forage available to support an animal's energy needs for body maintenance $\{$ net energy maintenance $(\mathrm{NEm})\}$, \{net energy lactation $(\mathrm{NEL})\}$, or body weight gain $\{$ net energy growth $(\mathrm{NEg})\}$. NEm and NEgare often used in balancing rations for growing cattle, and NEL is often used for dairy rations. Digestible Energy (DE) is the energy in forage that is not lost in feces. Metabolizable Energy (ME)estimates the energy in forage that is not lost in feces, urine, or rumen gases.

The main objectives of this study are localizing the know-how of using hydroponic culture in producing green fodder (sprout) in Egypt while investigated the suitable barley cultivar use under hydroponic culture.Determination digestibility values for green fodder by using in-vitro Daisy ${ }^{\text {II }}$ incubator and prediction nutritive, energy values from chemical composition to use in ruminant animal feeding.

\section{MATERIALS AND METHODS}

The experiment was carried out at Protected Cultivation Site, Central Laboratory for Agriculture Climate (CLAC), Agriculture Research Centre, Giza, Egypt during January and February 2017 under net house and replicated three times in this period.

\section{Plant material:}

Six barley (Hordeum vulgare L.) cv. cultivars seeds were evaluated in this study: Giza 123, Giza 126, Giza 127, Giza 128, Giza 129, and Giza 130. The different cultivars seeds were soaked in water separately, with the purpose of eliminating the whole material that floats. Then barley seeds were soaked in warm water $\left(40^{\circ} \mathrm{C}\right)$ containing $0.1 \%$ hypochlorite for 30 minutes then washed by tap water for 10 minutes. Planting trays also were cleaned and disinfected by using $0.1 \%$ hypochlorite and washed by tap water to remove any traces. Three growing periods during January and February 2017 were cultivated through one growing period each 8 day. Average, min, max and average temperature were recorded (Fig.1). 


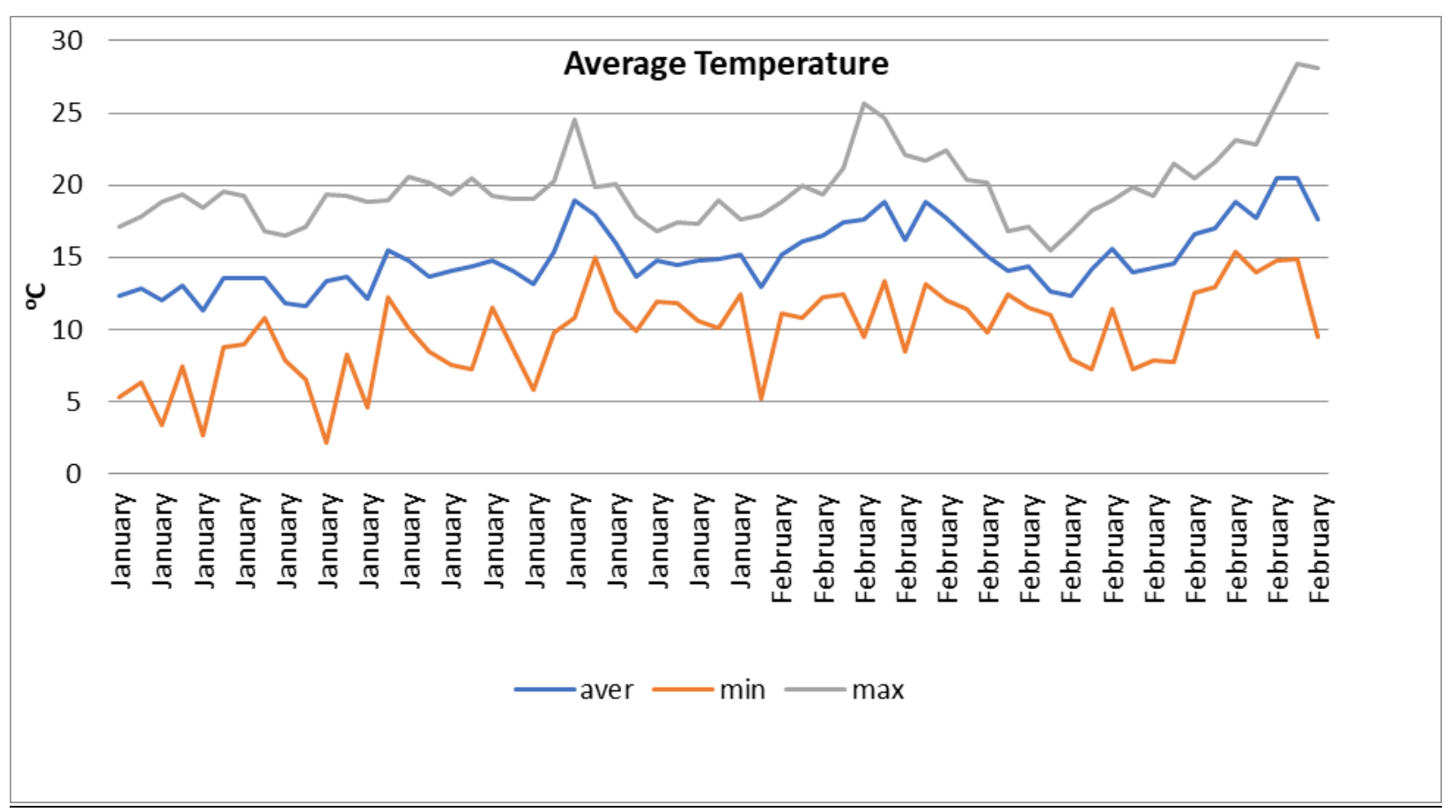

Fig: (1). Max, min and average temperature from January and February 2017 under the net house.

\section{Hydroponic system:}

Using intensive hydroponic system without inert material or soil for the process of barley germination, during each period ( 8 days) was done. The intensive hydroponic system constructed by using a steel stand, size $2.10 \times 0.50 \times 1.9 \mathrm{~m}$ equipped containing 6 shelves $(30 \mathrm{~cm}$ apart shelves $)$ with capacity of 42 polyethylene trays sized $60 \times 30 \times 3 \mathrm{~cm}\left(0.18 \mathrm{~m}^{2}\right)$ each (equivalent to about $\left.10 \mathrm{~kg} / \mathrm{m}^{2}\right)$ according to the results obtained by El-Morsy et al., 2013. The hydroponic unit was located under white net house and covered by black net (63\% shade) during the studied periods.

The irrigation of different shelves was designed depending on fog system. The irrigation water was delivered via 4 fog sprayers (32 L/hour) for each shelf. The fog system was automated by using digital timer ( 2 minutes/hour/24 hours) to control water pumping (water pump 0.5 horse powers) from water tank. Black polyethylene tank one cubic meter was used as irrigation water tank. The base of trays was holed to allow drainage of excess water of irrigation. The used water was tap water with free nutrient solution or any additives.

\section{Sprout yield characteristics:}

At the end of experiment ( 8 days after seeding), barley shoots and root mats (sprouts) in the trays of different cultivars were harvested and the following data were recorded total fresh and dry sprouts yields $(\mathrm{Kg})$, shoot height $(\mathrm{cm})$, and conversion factor (ratio of produced barley sprouts to the initial planted seed weight $(\mathrm{Kg} / \mathrm{Kg})$ were recorded.

\section{Chemical analysis:}

Representative samples of barley sprout (leaves plus roots) cultivar from each plot were air dried and taken for proximate analysis according to the procedures of AOAC (2000). Fiber fraction analysis: Natural detergent fiber (NDF), acid detergent fiber (ADF) and acid detergent lignin (ADL) contents of samples of barley sprout (leaves plus roots) were determined according to Van Soest et al. (1991). Cellulose (Cell.) and hemicellulose (Hem.) contents were calculated respectively, by subtracting (acid detergent lignin) ADL from ADF and ADF (acid detergent fiber) from (nutrient detergent fiber) NDF with using sodium sulfide by ANKOM 200 Fiber Analyzer (ANKOM, 2005).

\section{Energy prediction:}


Prediction of energy availability from laboratory analyses usually requires specific equations for each type of feed. The accuracy of energy predictions is a function of the accuracy of laboratory analyses and the accuracy of the animal experimentation used to develop the prediction equation, Available energy and digestibility cannot be measured in the laboratory and is estimated from chemical composition. Most energy values are predicted from fiber analyses because fiber is negatively related to the animal's ability to digest and use nutrients in the feed, the following equations according to N.R.C., (2001).

\section{Equations:}

$\mathrm{DCP}=$ digestible crude protein $=(\mathrm{CP} \% * 0.908)-3.77$

DMI $=$ Dry Matter Intake $=120 /$ NDF\%.

DDM= Dry Matter Digestibility\%= 88.9- $(0.779 *$ ADF\% $)$.

$\mathrm{TDN}=$ Total Digestible Nutrients $(100 \% \mathrm{DM})=96.35-(0.70 * \% \mathrm{ADF})$.

$\mathrm{NEL}=$ Net Energy of Lactation $(\mathrm{Mcal} / \mathrm{Lb}$. of DM $)=(\mathrm{TDN} \% \mathrm{X}$ 0.01114 $)-0.054$

$\mathrm{NEM}=$ Net Energy Maintenance $(\mathrm{Mcal} / \mathrm{Lb}$. of DM $)=(\mathrm{TDN} \% \mathrm{X}$ 0.01318 $)-132$.

NEG $=$ Net Energy Growth $($ Mcal/Lb of DM $)=($ TDN\%X0.01318 $)-0.459$.

$\mathrm{GE}=$ Growth Energy $(\mathrm{MJ} / \mathrm{Kg} \mathrm{DM})=0.0226 * \mathrm{CP}+0.0407 * \mathrm{EE}+0.0192 * \mathrm{CF}+0.0177 * \mathrm{NFC}$ according to Maff (1975)

$\mathrm{DE}=$ Digestible Energy $(\mathrm{Mcal} / \mathrm{Lb}$. of DM $)=(0.04409 * \mathrm{TDN}) / 2.204$.

$\mathrm{ME}=$ Metabolizable Energy $(\mathrm{Mcal} / \mathrm{Lb}$. of DM $)=(1.01 *(0.04409 * \mathrm{TDN}))-0.45) / 2.204$.

$\mathrm{NSC}=$ Non - Structure Carbohydrate $=100-(\mathrm{NDF} \%+\mathrm{CP} \%+\mathrm{EE} \%+\mathrm{ASH} \%)$ by $($ Mertens, 2002) .

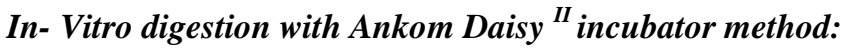

In vitro digestibility's of feed ingredients and experimental rations were done by using the Ankom Daisy ${ }^{\mathrm{II}}$ incubator procedure. The procedure followed is described in detail by Goeser and Combs (2009). Tilley and Terry (1963) were used for the determination of apparent dry matter digestibility (ADMD). True In-vitro DM digestibility (TDMD) was determined by measuring the neutral detergent fiber (NDF) in the residue from the incubation with rumen inoculum and buffer. Neutral detergent fiber digestibility (NDFD) was determined with Ankom Daisy ${ }^{\text {II }}$ incubator procedure. In -Vitro true digestibility and NDFD were calculated according to Ankom Daisy II incubator method.

\section{Economic efficiency:}

Economic study depends on the cost and profit of the producing sprout of different cultivars barley was done. The cost and profit were calculated instead of the hydroponic system and labor costs to clarify the economics of different cultivars treatments. The profit and biomass rate were calculated as follows:

The profit $(\mathrm{LE} / \mathrm{m} 2)=$ production $(\mathrm{LE} / \mathrm{m} 2)-$ cost of seeds $(\mathrm{LE} / \mathrm{m} 2)$.

Biomass rate $=$ total sprout fresh weight $(\mathrm{kg} / \mathrm{m} 2) /$ seeds weight $(\mathrm{kg} / \mathrm{m} 2)$.

\section{Experimental design and statistical analysis:}

Completely randomized blocks design was used with four replicates. Statistical analysis was determined by computer, using SAS program for statistical analysis. The differences among means for all traitswere tested for significance at 5\% level according to the procedure described by Snedicor and Cochran (1981). The data of the three growing periods were analyzed and presented in this study as an average according to the high similarity results and to avoid the results duplication.

\section{RESULTS AND DISCUSSION}

\section{The vegetative characteristics of sprouting produced by different barley cultivars:}

The average production of different barley cultivars in hydroponic system $(\mathrm{kg} / \mathrm{day})$ during the three sprouting period in Table (1). The results indicated that the sprouting of green barley fodder can be produced 
in 8 days from planting to harvest using hydroponic technique for barley cultivars crops (Giza 123, Giza 126, Giza 127, Giza 128, Giza 129, and Giza 130). The data revealed that the changes of average sprout weight for tested cultivars were non-significant until the third day of the growing period while in the fourth day the cultivars changed their weight of sprouts $(\mathrm{P}<0.05 \%)$ significantly. The highest significant average sprout weight value was recorded by Giza127(6.98 Kg) followed by Giza 129 (6.83 Kg) then Giza 128 (6.09 $\mathrm{Kg})$. On the other hand, Giza 126 had the lowest value $(5.09 \mathrm{Kg})$ of average fresh barley sprout weight. These results are the same to that was reported previously by Shtaya (2004). Grains of barley gained weight over the 8 days sprouting period as a result of water imbibitions.

Table (1): The average production of different barley cultivars in hydroponic system (kg/day) during the growing period.

\begin{tabular}{|c|c|c|c|c|c|c|c|c|}
\hline \multicolumn{9}{|c|}{ Average production during three growing periods } \\
\hline & \multicolumn{8}{|c|}{ Days after sowing (kg/day) } \\
\hline Cultivar & Day 1 & Day 2 & Day 3 & Day 4 & Day 5 & Day 6 & Day 7 & Day 8 \\
\hline Giza 123 & 1 & $1.41^{\mathrm{a}}$ & $1.98^{\mathrm{a}}$ & $2.19^{\mathrm{c}}$ & $2.93^{\mathrm{b}}$ & $3.90^{\mathrm{c}}$ & $4.42^{\mathrm{c}}$ & $5.16^{\mathrm{d}}$ \\
\hline Giza 126 & 1 & $1.39^{\mathrm{a}}$ & $1.89^{\mathrm{a}}$ & $2.18^{\mathrm{c}}$ & $2.97^{\mathrm{b}}$ & $3.72^{\mathrm{c}}$ & $4.04^{\mathrm{d}}$ & $5.09^{\mathrm{d}}$ \\
\hline Giza 127 & 1 & $1.35^{\mathrm{a}}$ & $1.89^{\mathrm{a}}$ & $2.47^{\mathrm{a}}$ & $3.44^{\mathrm{a}}$ & $4.67^{\mathrm{a}}$ & $5.54^{\mathrm{a}}$ & $6.98^{\mathrm{a}}$ \\
\hline Giza 128 & 1 & $1.35^{\mathrm{a}}$ & $1.95^{\mathrm{a}}$ & $2.45^{\mathrm{ab}}$ & $3.34^{\mathrm{a}}$ & $4.33^{\mathrm{b}}$ & $5.02^{\mathrm{b}}$ & $6.09^{\mathrm{b}}$ \\
\hline Giza 129 & 1 & $1.39^{\mathrm{a}}$ & $1.99^{\mathrm{a}}$ & $2.41^{\mathrm{ab}}$ & $3.35^{\mathrm{a}}$ & $4.46^{\mathrm{ab}}$ & $5.59^{\mathrm{a}}$ & $6.83^{\mathrm{a}}$ \\
\hline Giza 130 & 1 & $1.34^{\mathrm{a}}$ & $1.94^{\mathrm{a}}$ & $2.3^{\mathrm{bc}}$ & $3.02^{\mathrm{b}}$ & $3.90^{\mathrm{c}}$ & $4.37^{\mathrm{c}}$ & $5.60^{\mathrm{c}}$ \\
\hline
\end{tabular}

* Means in each column followed by the same letter are not significantly different at 5\% probability.

The average daily ratio of fresh sprout weight for barley tested cultivars during the growing period was show in Fig. (2). The average fresh weight was increased weight in general about 1.41 to 1.34 times, their original pre-steeped weight after 1 day, the range from 1.45 to 1.36 times after 2 days, the range from 1.45 to 1.11 times after 3 days, the range from 1.31 to 1.11 times after 4 days, the range from 1.39 to 1.31 times after 5 days then the increment ratio start to decrease down to 1.36 to 1.25 times after 6 days and 1.28 to 1.17 times after 7 days. According to Peer and Leeson(1985a) fresh weight was increased from 1.72 times of the original seed weight, after 1 day of sprouting, the white tip of the radical is visible. By the third day, the radical has branched and the blade inside the heath has turned green. After the fourth day, a green blade has protruded above the sheath and the roots of the kernels have formed a definite mat with other kernels. From the first and eighth day, the main visible change is the increase in root length and thickness. The effect of different barley cultivars in hydroponic system on shoot height of barley sprout was presented in Fig. (3). Data showed that the highest shoot was obtained with Giza 127 followed by Giza $129(10 \mathrm{~cm}$ and $9.5 \mathrm{~cm}$, respectively) and there were no significant differences between them. The lowest shoot height was obtained with Giza $126(6.2 \mathrm{~cm})$. Similar values were obtained by Al-Hashmi (2008) regarding to the sprout's height of hydroponic barley. However, the average sprout heights of barley cultivars showed significant differences among them.

\section{Fresh sprout weight:}

Seeds weight ratio of different cultivars was illustrated in Fig. (4), the results indicated that the highest value 5.81 of fresh sprout: seeds weight ratio (5.81 and 5.66) was recorded significantly by Giza 127 followed by Giza 129 (5.66) compared to the other four cultivars. These values are the same to that the fresh sprout weight: seeds weight ratio the ranged from 5.81 to 3.86. Similar results were obtained by AlHashmi (2008) and Al-Karaki (2010) who reported that the ratio reached up to 8 times in barley sprouts produced via intensive hydroponic system but under full control system.Peer and Leeson(1985a)found that seed soaking leads to the activation of enzymes and solubilization and digestion of starch stored in the endosperm to simple sugars of the starch stored in the endosperm to simple sugars. This provides substrate for the young developing plant for metabolic activities. These substrates are respired to produce energy, giving off carbon dioxide and water. This loss of carbon dioxide leads to a loss in dry matter. These results 
were in accordance with those of Bautista(2002) and Morgan et al., (1992) who reported a significant difference in wet weight (WW) and dry weight (DW) of the hydroponic fodder.

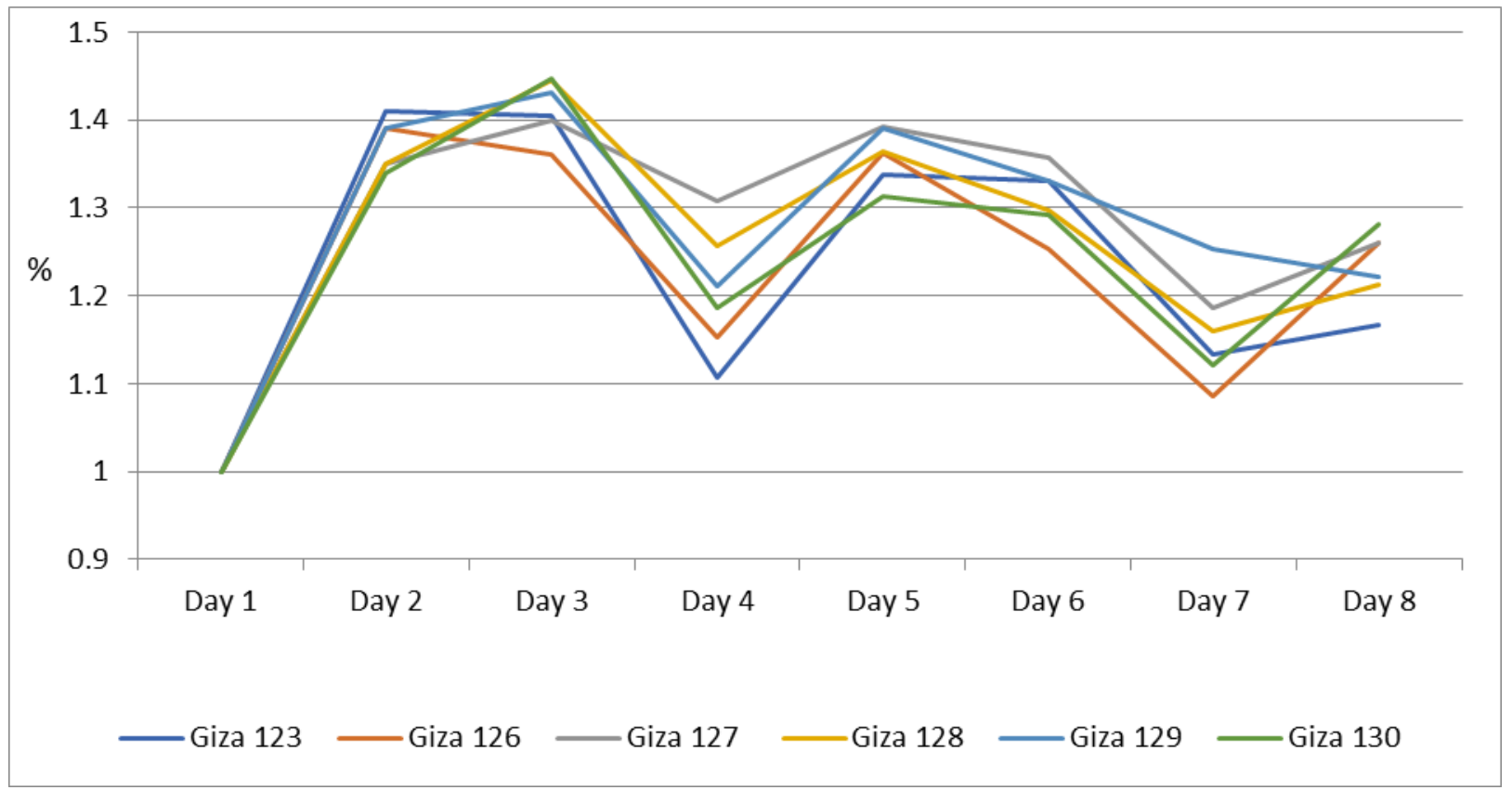

Fig. (2): The average of fresh barley sprouts weight increase / day ratio during the growing period.

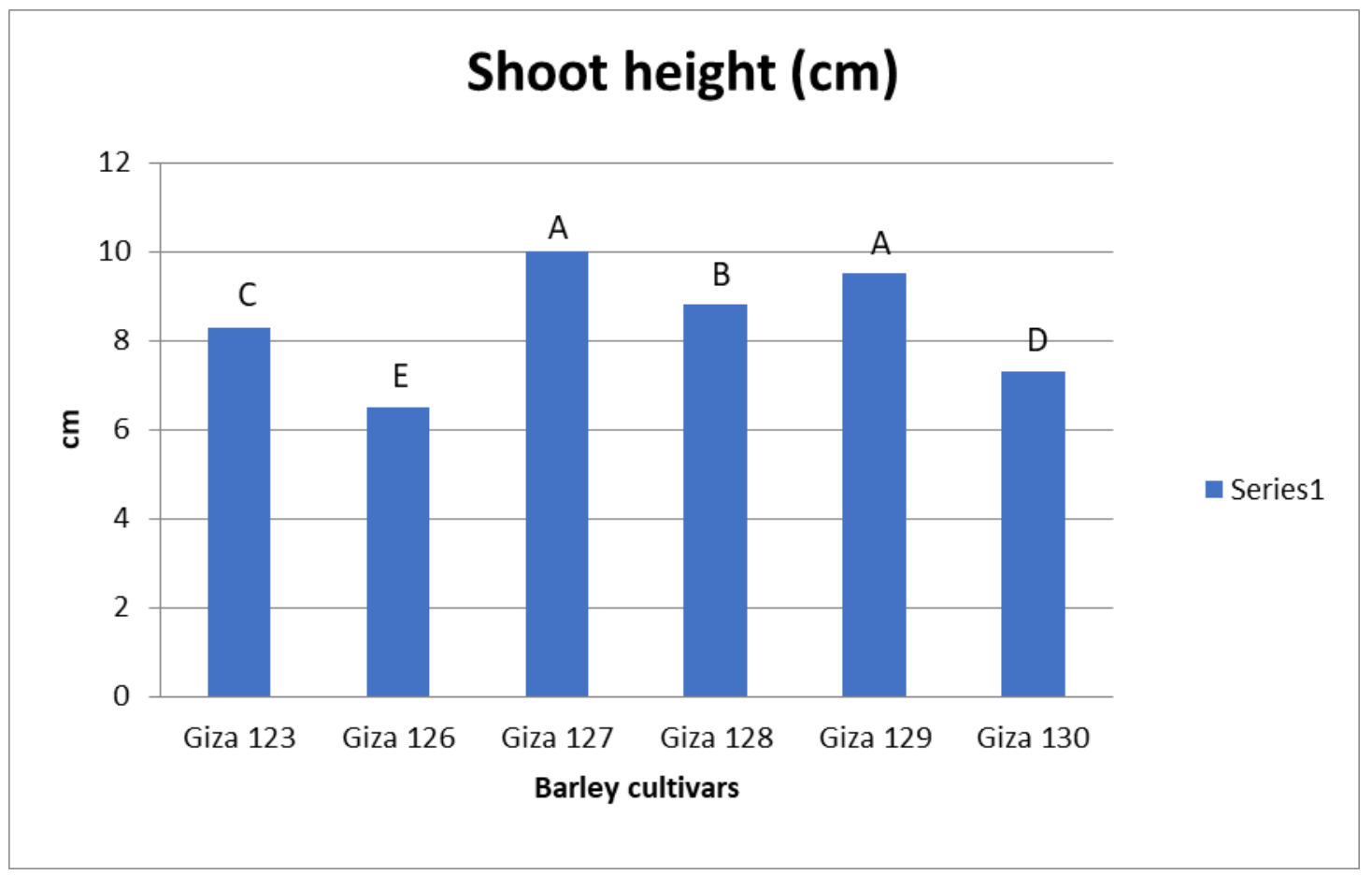

Fig. (3): The effect of barley cultivars on shoot height (cm). 


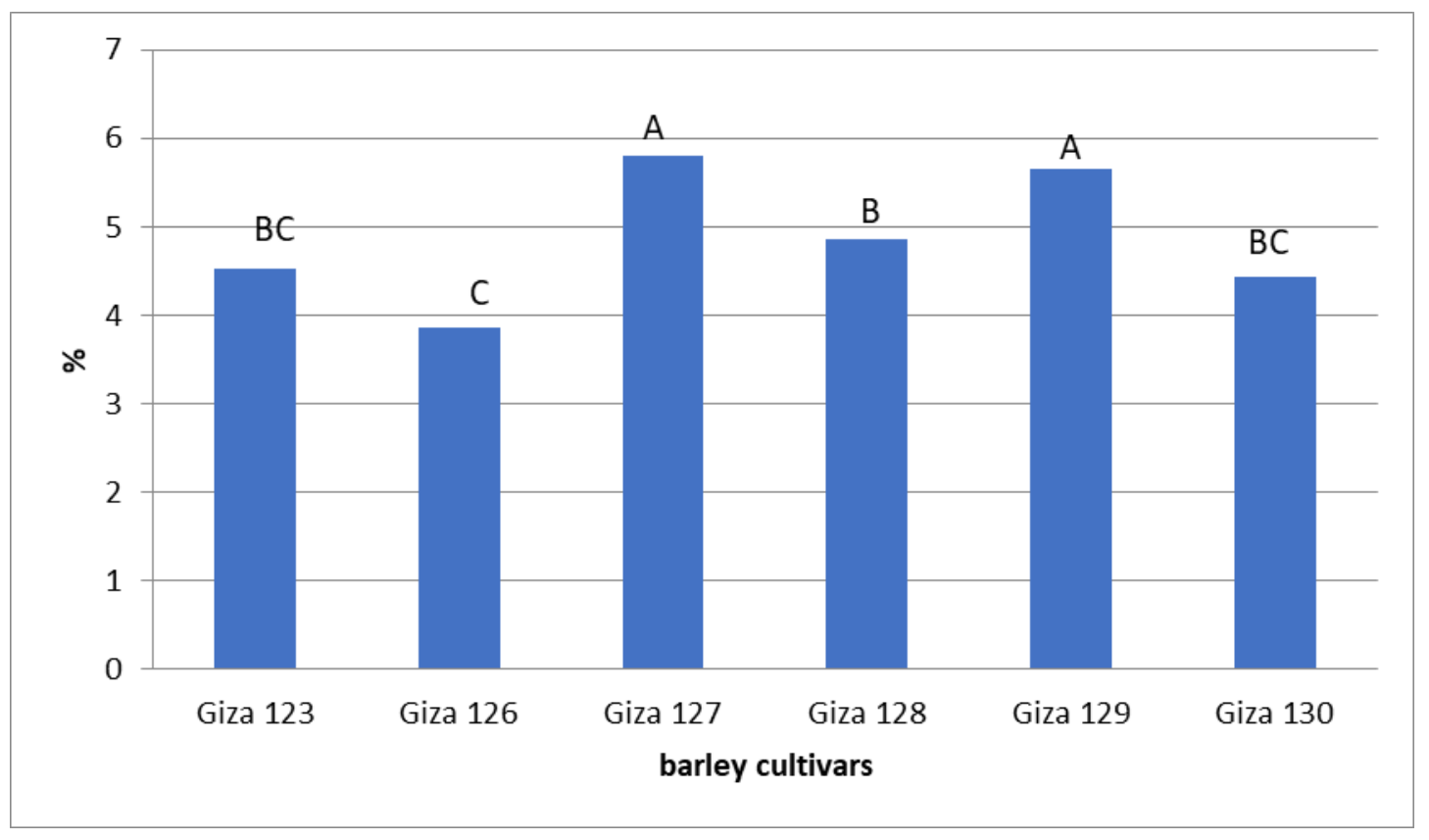

Fig. (4): The average of barley sprout weight: seeds weight ratio of different barley cultivars.

\section{Chemical composition:}

Chemical composition of the several un-sprouted seeds barley strain and its cultivatorsgreen fodder barley (sprouted) were produced at a hydroponicare shown in Table (2). The significant $(\mathrm{P}<0.05)$ increase DM in sprouting barley by means (87.89\%) compares with other seeds (91.97\%). But there are insignificant values between several un-sprouted seeds barley and also between several cultivator's green fodder barley test strain.

An insignificant $(\mathrm{P}<0.05)$ differences among several cultivator'sgreen fodder of Egyptian barley in mean values was found only in the case of DM (range 91.22 to 92.37). The significantly $(\mathrm{P}<0.05)$ increase OM of sprouting barley green compared with its seed. Chavan and Kadam (1989) found the nutrients changes in sprouting grains by enhancing the time of sprouting, the higher organic matter, particularly starch consumed to support the metabolism and energy requirement of the growing.

The $\mathrm{CP} \%$ values in several cultivator green fodder barley strains significant $(\mathrm{P}<0.05)$ increase(the range from 11.56 to $13.45 \%$ ) compared with its un- sprouting strains (the range from( 9.58 to $12.60 \%$ ) of Giza123, 126, 127 and 128 except cultivator green fodder barley(Giza 129 and Giza 130) the CP values (8.84 and $10.3 \%)$ were significant $(\mathrm{P}<0.05)$ decrease compared with un-sprouted barley strains $(11.97$ and $11.04 \%)$ but the highest values was observed with green fodder barley specie (Giza 127) (13.45\%). The CP contents could be affected by the cultivation conditions in hydroponic systems. The CP obtained in this study was comparable with those reported by Al-Ajmi et al., (2009) and Morgan et al. (1992) reported that CP content was increased from 10.8 at day 4 to 14.9 percent at day 8 in hydroponically barley fodder that were in accordance with our findings. But, Snow et al. (2008) reported that a higher CP content (16.13\%) was recorded with the hydroponically barley fodder. Sneath and McIntosh (2003) evaluated the composition of sprouted barley and reported that the CP ranged from 11.38 to 24 percent. Chavan and Kadam (1989) observed increases in protein quality in sprouting barley, very complex qualitative changes are reported to occur during soaking and sprouting of seeds. The conversion of storage proteins of cereal grains into albumins and globulins during sprouting may improve the quality of cereal proteins. Many studies have shown an increase in the content of the amino acid Lysine with sprouting. An increase in proteolytic activity during sporting is desirable for nutrition improvement of cereals because it leads to hydrolysis of prolamins and the liberated amino acids such as glutamic and proline are converted to limiting amino acids such as lysine. 
There were a significantly $(\mathrm{P}<0.05)$ increase for $\mathrm{CF} \%$ between with green fodder barley species (the range from 9.93 to 14.36) in 8- days sprouting compared with several un-sprouted barley strains (the range from 5.67 to $8.85 \%$ ), and there were significant values between several strain barely Also, the EE were significant increased values between seeds and sprouting except (Giza 129 and Giza 130) were slightly decreased. Peer and Leeson (1985b), stated that, crude fiber in sprouting green barley a major constituent of cell walls, increases both in percentage and real terms, with the synthesis of structural carbohydrates, such as cellulose and hemicellulose. This result is agreement with Chung et al., (1989) who found that the fiber content increased from 5.4\% un-sprouted barley seed to $14.1 \%$ after 7-days sprouting.

The NFE and NSC were significantly decreased $(\mathrm{p}<0.05)$ in Green fodder barley (GF) compared to the other barley seed except green fodder barley (Giza 123) was significant $(\mathrm{P}<0.05)$ increase in the value NFE, there were significant different between several Egyptian sprouted and several seed strain.Ash values in several green fodder barleys are decreased compared with its barley seed this result according to Kent and Amos (1967)observed after 6 days of growing, starch accounted for 53-67\% of the dry weight of barley seed, so any decrease in the amount of starch would cause a corresponding decrease in NFE and DM as well. The increase in EE could be due to the production of chlorophyll associated with plant growth that is recovered in ether extract measurement (Mayer and Poljakoff-Mayber (1975). Such changes in nutrients profile and recovery are misleading since they only described the alterations in the proportion of nutrients during growth and sprouting of seeds (Morgan et al., 1992). A change in weight of any one of the nutrient leaded to proportional changes in other compositions. During the germination and early stage of plant growing, starch was catabolized to soluble sugars for use in respiration and cell-wall synthesis (Morganetal,.1992). Morgan et al. (1992)who found that ash content of sprouts increased from day 4 corresponding with the extension of the root, which allowed mineral uptake. They reported that ash content changed from 2.1 in original seed (barley) to 3.1 and 5.3 at day 6 and 8, respectively and they recorded DM losses ranging $7-18 \%$ which is mostly non-fiber carbohydrate. In the other hand, the structural carbohydrate increased in sprout green forage. These changes affected the proportion of the other nutrients such as protein that could be shown a higher percentage. Fazaeli et al., (2012) reported that, the Ash, EE, NDF, ADF and WSC were increased but OM and NFC decreased $(\mathrm{p}<0.05)$ in GF compared to the initial barley grain. The $\mathrm{CP}$ content was significantly $(\mathrm{p}<0.05)$ increased only at day 8 . By extending the growing period from day 6 to day 8 , the CP, Ash, EE, NDF and ADF were increased but NFC and WSC reduced.

\section{Fiber fraction:}

The effect comparison of used some Egyptian barley cultivars for green fodder production in intensive hydroponic system of six barley cultivars (Giza 128, Giza 127, Giza 130, Giza 129, Giza 126, and Giza 123) under hydroponic in the present investigation, fiber fraction of the several seed barley and several cultivator Green fodder barleys were produced at a hydroponic are shown in table (3). The NDF, ADF, ADL, acid insoluble ash values in several cultivator green fodder barley strain was significant increase compared with several original barley seeds. The highest significant values NDF and cellulose were recorded (37.47\% and $20.85 \%$ ) with sprouting (Giza 123) compared several cultivator Green fodder barley strains, but ADF was recorded (17.93\%) with sprouting (Giza 127). The highest significant values ADL and AIA were recorded (5.91\%and $1.78 \%$ ) with sprouting (Giza 130) compared several cultivator green fodder barley strains. The highest significant values celluloses were recorded (12.63\%) with sprouting (Giza 126) compared several cultivator green fodder barley strains. however; significant increased NDF-cell soluble was recorded $(80.88 \%)$ with (Giza 130). The different significant values between the several Egyptian strains in fiber fraction determination. The NDF and ADF were increased but NDF-cell soluble reduced obtained in this study was agreement with Fazaeli et. al. (2012).

\section{Predicting feeding valuesfrom chemical composition:}

Results in table (4) observed significant increase of DCP between seed barley and several cultivator Green fodder barleys except Giza (129) and (130). The highest result values of DCP cultivator Green fodder barley was recorded with (Giza127) the value increase from7.67\% in seed to $8.44 \%$ in sprouting Green fodder. The DDM and DMI were significantly decreased in all several cultivator Green fodder barleys compared with its seed. Also, several cultivator Green fodder barley productions observed significantly decreased of TDN in all strains compared with its seeds. The significant highly means values of sprouting several barleys compared with its seed of digestible protein, but the means value of DDM, TDN and DMI were significant decrease in sprouting barley compared with its seed. The means values between different strains significant different, the best strain of TDN and DMI recorded with Giza (129) and DCP recorded with Giza (127) 
Table (2): The effect of sprouting produced by different barley cultivars on chemical composition: -

\begin{tabular}{|c|c|c|c|c|c|c|c|c|c|}
\hline \multirow[t]{2}{*}{ Cultivar } & Seed & sprout & Mean & Seed & Sprout & Mean & Seed & Sprout & Mean \\
\hline & \multicolumn{3}{|c|}{ Dry matter (DM) } & \multicolumn{2}{|c|}{$\mathrm{OM}$} & \multicolumn{4}{|c|}{ Crude protein $(\mathrm{CP})$} \\
\hline Giza 123 & $88.02^{b}$ & $92.28^{\mathrm{a}}$ & $90.15 \mathrm{~A}$ & $82.48^{\mathrm{bc}}$ & $89.32 \mathrm{a}$ & $95.75 \mathrm{~A}$ & $11.95^{\mathrm{abc}}$ & $12.64^{\mathrm{ab}}$ & $12.29 \mathrm{~A}$ \\
\hline Giza 126 & $87.92^{\mathrm{b}}$ & $91.93^{\mathrm{a}}$ & 89.93 B & $81.55^{\mathrm{c}}$ & $88.37^{\mathrm{ab}}$ & $95.04 \mathrm{~A}$ & $10.58^{\text {cde }}$ & $13.13^{\mathrm{a}}$ & $\begin{array}{c}11.85 \\
\mathrm{AB}\end{array}$ \\
\hline Giza 127 & $87.82^{b}$ & $92.37^{\mathrm{a}}$ & $90.15 \mathrm{~A}$ & $82.71^{\mathrm{bc}}$ & $92.37^{\mathrm{a}}$ & $95.38 \mathrm{~A}$ & $12.60^{\mathrm{ab}}$ & $13.45^{\mathrm{a}}$ & $13.03 \mathrm{~A}$ \\
\hline Giza 128 & $88.26^{b}$ & $92.1^{\mathrm{a}}$ & $90.18 \mathrm{~A}$ & $79.95^{\mathrm{d}}$ & $92.1^{\mathrm{a}}$ & $93.72 \mathrm{~B}$ & $9.58^{\mathrm{de}}$ & $11.56^{\mathrm{abc}}$ & $10.57 \mathrm{BC}$ \\
\hline Giza 129 & $87.54^{b}$ & $91.93^{\mathrm{a}}$ & $89.74 \mathrm{~A}$ & $82.68^{\mathrm{abc}}$ & $88.30^{\mathrm{ab}}$ & $95.76 \mathrm{~A}$ & $11.97^{\mathrm{abc}}$ & $8.84^{\mathrm{e}}$ & $10.41 \mathrm{C}$ \\
\hline Giza 130 & $87.78^{\mathrm{b}}$ & $91.22^{\mathrm{a}}$ & $89.51 \mathrm{~A}$ & $82.37^{\mathrm{bc}}$ & $87.30^{\mathrm{ab}}$ & $95.34 \mathrm{~A}$ & $11.04^{\mathrm{bcd}}$ & $10.30^{\text {cde }}$ & $10.67 \mathrm{BC}$ \\
\hline \multirow[t]{2}{*}{ Mean } & $87.89 \mathrm{~B}$ & $91.97 \mathrm{~A}$ & & $94.16 \mathrm{~B}$ & $96.26 \mathrm{~A}$ & & $11.28 \mathrm{~A}$ & $11.65 \mathrm{~A}$ & \\
\hline & \multicolumn{3}{|c|}{ Ether extract (EE) } & \multicolumn{2}{|c|}{ ASH } & & \multicolumn{2}{|c|}{$\begin{array}{c}\text { Nitrogen free extract } \\
\text { (NFE) }\end{array}$} & \\
\hline \multirow[t]{2}{*}{ Giza 123} & $3.25^{\mathrm{c}}$ & $3.49^{\mathrm{b}}$ & $3.37 \mathrm{~B}$ & $5.54^{\mathrm{c}}$ & $2.96^{\mathrm{i}}$ & $4.25 \mathrm{D}$ & $70.41^{\mathrm{h}}$ & $71.22^{f}$ & $70.82 \mathrm{D}$ \\
\hline & $2.62^{\mathrm{e}}$ & $2.81^{\mathrm{d}}$ & $2.72 \mathrm{D}$ & $6.37^{\mathrm{b}}$ & $3.56_{\mathrm{h}}$ & $4.97 \mathrm{~B}$ & $72.79^{\mathrm{d}}$ & $67.32^{1}$ & $70.15 \mathrm{~F}$ \\
\hline \multicolumn{10}{|l|}{ Giza 126} \\
\hline Giza 127 & $3.30^{\mathrm{c}}$ & $3.71^{\mathrm{a}}$ & $3.51 \mathrm{~A}$ & $5.11^{\mathrm{d}}$ & $4.14^{\mathrm{f}}$ & $4.63 \mathrm{C}$ & $72.50^{\mathrm{e}}$ & $67.71^{\mathrm{k}}$ & $70.11 \mathrm{E}$ \\
\hline Giza 128 & $2.10^{\mathrm{f}}$ & $3.24^{\mathrm{c}}$ & $2.67 \mathrm{D}$ & $8.31^{\mathrm{a}}$ & $4.25^{\mathrm{f}}$ & $6.28 \mathrm{~A}$ & $75.35^{\mathrm{a}}$ & $70.18^{\mathrm{i}}$ & $72.77 \mathrm{~A}$ \\
\hline Giza 129 & $2.90^{\mathrm{d}}$ & $2.58^{\mathrm{e}}$ & $2.74 \mathrm{D}$ & $4.86^{\mathrm{e}}$ & $3.63^{\mathrm{h}}$ & $4.24 \mathrm{D}$ & $74.60^{\mathrm{b}}$ & $70.58^{\mathrm{g}}$ & $72.59 \mathrm{~B}$ \\
\hline Giza 130 & $3.24^{\mathrm{c}}$ & $2.94^{\mathrm{d}}$ & $3.09 \mathrm{C}$ & $5.41^{\mathrm{c}}$ & $3.92^{\mathrm{g}}$ & $4.66 \mathrm{C}$ & $73.46^{\mathrm{c}}$ & $69.65^{\mathrm{j}}$ & $71.56 \mathrm{C}$ \\
\hline \multirow[t]{2}{*}{ Mean } & $2.90 \mathrm{~B}$ & $3.13 \mathrm{~A}$ & & $5.93 \mathrm{~A}$ & $3.74 \mathrm{~B}$ & & $73.19 \mathrm{~A}$ & $69.44 \mathrm{~B}$ & \\
\hline & \multicolumn{3}{|c|}{ Crude fiber (CF) } & \multicolumn{2}{|c|}{$(\mathrm{NFC} \%)$} & & & & \\
\hline Giza 123 & $8.85^{\mathrm{g}}$ & $9.93^{\mathrm{f}}$ & $9.39 \mathrm{D}$ & $57.78^{\mathrm{f}}$ & $43.67^{\mathrm{j}}$ & $50.73 \mathrm{E}$ & & & \\
\hline Giza 126 & $7.64^{\mathrm{h}}$ & $13.18^{\mathrm{c}}$ & $10.41 \mathrm{~A}$ & $58.31^{\mathrm{e}}$ & $46.47^{\mathrm{i}}$ & $52.39 \mathrm{D}$ & & & \\
\hline Giza 127 & $6.49^{j}$ & $10.97^{\mathrm{d}}$ & $8.73 \mathrm{E}$ & $59.87^{\mathrm{c}}$ & $41.47^{\mathrm{k}}$ & $50.67 \mathrm{E}$ & & & \\
\hline Giza 128 & $4.66^{1}$ & $10.77^{\mathrm{e}}$ & $7.71 \mathrm{~F}$ & $59.49^{\mathrm{d}}$ & $47.76^{\mathrm{h}}$ & $53.63 \mathrm{C}$ & & & \\
\hline Giza 129 & $5.67^{\mathrm{k}}$ & $14.36^{\mathrm{a}}$ & $10.02 \mathrm{C}$ & $60.95^{\mathrm{a}}$ & $57.78^{\mathrm{f}}$ & $59.36 \mathrm{~A}$ & & & \\
\hline Giza 130 & $6.85^{\mathrm{i}}$ & $13.63^{\mathrm{b}}$ & $10.24 \mathrm{~B}$ & $60.65^{\mathrm{b}}$ & $52.91^{\mathrm{g}}$ & $56.78 \mathrm{~B}$ & & & \\
\hline Mean & $6.69 \mathrm{~B}$ & $12.14 \mathrm{~A}$ & & $59.51 \mathrm{~A}$ & 48.34 B & & & & \\
\hline
\end{tabular}


Table (3):The effect of sprouting produced by different barley cultivarson fiber fraction:

\begin{tabular}{|c|c|c|c|c|c|c|c|c|c|}
\hline \multirow[t]{2}{*}{ Cultivar } & Seed & Sprout & Mean & seed & sprout & Mean & seed & Sprout & Mean \\
\hline & \multicolumn{2}{|c|}{ NDF $\%$} & & \multicolumn{2}{|c|}{ ADF $\%$} & \multicolumn{4}{|c|}{ ADL \% } \\
\hline Giza 123 & $21.48^{\mathrm{h}}$ & $37.47^{\mathrm{a}}$ & $29.5 \mathrm{~A}$ & $8.11^{\mathrm{f}}$ & $16.62^{b}$ & $12.4 \mathrm{~B}$ & $1.76_{i}$ & $5.40^{\mathrm{b}}$ & $3.6 \mathrm{C}$ \\
\hline Giza 126 & $22.12^{\mathrm{g}}$ & $34.03^{\mathrm{c}}$ & $28.1 \mathrm{C}$ & $8.03^{\mathrm{f}}$ & $16.64^{b}$ & $12.4 \mathrm{~B}$ & $1.83^{\mathrm{h}}$ & $4.01^{\mathrm{e}}$ & $2.9 \mathrm{E}$ \\
\hline Giza 127 & $19.12^{1}$ & $37.23^{\mathrm{b}}$ & $28.2 \mathrm{~B}$ & $7.09^{\mathrm{g}}$ & $17.93^{\mathrm{a}}$ & $12.5 \mathrm{~A}$ & $2.12^{\mathrm{g}}$ & $5.30^{\mathrm{c}}$ & $3.7 \mathrm{~B}$ \\
\hline Giza 128 & $20.52^{\mathrm{i}}$ & $33.19^{\mathrm{d}}$ & $26.8 \mathrm{D}$ & $6.86^{\mathrm{h}}$ & $15.74^{\mathrm{c}}$ & $11.3 \mathrm{C}$ & $1.86^{\mathrm{h}}$ & $5.07^{\mathrm{d}}$ & $3.5 \mathrm{D}$ \\
\hline Giza 129 & $19.32^{\mathrm{k}}$ & $27.17^{\mathrm{f}}$ & $23.2 \mathrm{~F}$ & $5.59^{\mathrm{j}}$ & $12.51^{\mathrm{d}}$ & $9.1 \mathrm{D}$ & $3.83^{\mathrm{f}}$ & $3.83^{\mathrm{f}}$ & $3.8 \mathrm{~A}$ \\
\hline Giza 130 & $19.66^{\mathrm{j}}$ & $29.93^{\mathrm{e}}$ & $24.8 \mathrm{E}$ & $6.73^{i}$ & $11.47^{\mathrm{e}}$ & $9.1 \mathrm{D}$ & $1.69^{\mathrm{j}}$ & $5.91^{\mathrm{a}}$ & $3.8 \mathrm{~A}$ \\
\hline Mean & $20.4 \mathrm{~B}$ & $33.2 \mathrm{~A}$ & & $7.1 \mathrm{~B}$ & $15.2 \mathrm{~A}$ & & $2.2 \mathrm{~B}$ & $4.9 \mathrm{~A}$ & \\
\hline \multicolumn{4}{|c|}{ Hemicellulose \% } & \multicolumn{2}{|c|}{ Cellulose $\%$} & \multicolumn{4}{|c|}{ Lignin \% } \\
\hline Giza 123 & $13.37^{\mathrm{h}}$ & $20.85^{\mathrm{a}}$ & $17.1 \mathrm{~A}$ & $6.36^{\mathrm{f}}$ & $11.22^{\mathrm{b}}$ & $8.8 \mathrm{~B}$ & $1.76^{\mathrm{hi}}$ & $4.50^{\mathrm{b}}$ & $3.1 \mathrm{~B}$ \\
\hline Giza 126 & $14.11^{\mathrm{f}}$ & $17.39^{\mathrm{c}}$ & $15.7 \mathrm{C}$ & $6.19^{\mathrm{g}}$ & $12.63^{\mathrm{a}}$ & $9.4 \mathrm{~A}$ & $1.83^{\mathrm{gh}}$ & $3.00^{\mathrm{e}}$ & $2.4 \mathrm{E}$ \\
\hline Giza 127 & $12.03^{\mathrm{j}}$ & $19.90^{\mathrm{b}}$ & $15.9 \mathrm{~B}$ & $4.97^{\mathrm{i}}$ & $10.67^{\mathrm{c}}$ & $7.8 \mathrm{C}$ & $2.12^{\mathrm{f}}$ & $4.61^{\mathrm{a}}$ & $3.4 \mathrm{~A}$ \\
\hline Giza 128 & $13.66^{\mathrm{g}}$ & $17.45^{\mathrm{c}}$ & $15.5 \mathrm{D}$ & $5.03^{\mathrm{h}}$ & $8.57^{\mathrm{d}}$ & $6.8 \mathrm{D}$ & $1.86^{\mathrm{g}}$ & $4.17^{\mathrm{c}}$ & $3.0 \mathrm{C}$ \\
\hline Giza 129 & $13.74^{\mathrm{g}}$ & $14.65^{\mathrm{e}}$ & $14.2 \mathrm{E}$ & $3.89^{\mathrm{j}}$ & $8.57^{\mathrm{d}}$ & $6.2 \mathrm{E}$ & $1.70^{\mathrm{i}}$ & $3.16^{\mathrm{d}}$ & $2.4 \mathrm{E}$ \\
\hline Giza 130 & $12.94^{\mathrm{i}}$ & $15.46^{\mathrm{d}}$ & $14.2 \mathrm{E}$ & $5.04^{\mathrm{h}}$ & $7.14^{\mathrm{e}}$ & $6.1 \mathrm{~F}$ & $1.69^{\mathrm{i}}$ & $4.13^{\mathrm{c}}$ & $2.9 \mathrm{D}$ \\
\hline Mean & $13.3 \mathrm{~B}$ & $17.6 \mathrm{~A}$ & & $5.2 \mathrm{~B}$ & $9.8 \mathrm{~A}$ & & $1.8 \mathrm{~B}$ & $3.9 \mathrm{~A}$ & \\
\hline \multicolumn{10}{|c|}{$\begin{array}{c}\text { NDF-cell. soluble } \\
\%\end{array}$} \\
\hline Giza 123 & $0.70^{\mathrm{e}}$ & $0.89^{\mathrm{c}}$ & $0.79 \mathrm{~B}$ & $78.52^{\mathrm{e}}$ & $62.53^{1}$ & $70.5 \mathrm{~F}$ & & & \\
\hline Giza 126 & $0.53^{\mathrm{g}}$ & $1.00^{\mathrm{b}}$ & $0.76 \mathrm{C}$ & $77.88^{\mathrm{f}}$ & $65.97^{\mathrm{j}}$ & $71.9 \mathrm{D}$ & & & \\
\hline Giza 127 & $0.62^{\mathrm{f}}$ & $0.69^{\mathrm{e}}$ & $0.65 \mathrm{D}$ & $80.88^{\mathrm{a}}$ & $62.76^{\mathrm{k}}$ & $71.8 \mathrm{E}$ & & & \\
\hline Giza 128 & $0.75^{\mathrm{d}}$ & $0.89^{c}$ & $0.82 \mathrm{~B}$ & $79.48^{\mathrm{d}}$ & $66.81^{\mathrm{i}}$ & $73.1 \mathrm{C}$ & & & \\
\hline Giza 129 & $0.66^{\mathrm{ef}}$ & $0.68^{\mathrm{e}}$ & $0.67 \mathrm{D}$ & $80.68^{\mathrm{b}}$ & $72.83^{\mathrm{h}}$ & $76.8 \mathrm{~A}$ & & & \\
\hline Giza 130 & $0.68^{\mathrm{e}}$ & $1.78^{\mathrm{a}}$ & $1.23 \mathrm{~A}$ & $80.34^{\mathrm{c}}$ & $73.07^{\mathrm{g}}$ & $76.7 \mathrm{~B}$ & & & \\
\hline Mean & $0.66 \mathrm{~B}$ & $0.98 \mathrm{~A}$ & & $79.6 \mathrm{~A}$ & $67.3 \mathrm{~B}$ & & & & \\
\hline
\end{tabular}

$N D F=$ Neutraldetergent fiber, $A D F=$ acid detergent fiber, $A D L=$ acid detergent lignin,

Hem= hemicellulose, Cell= cellulose, AIA= acid insoluble ash .

$a, b, d, f, g, h, k, l, i, j, e$ means with difference latter at the same column are significantly $(p,<0.05)$ different 
Table (4): The effect sprouting produced by different barley cultivars on predicting feeding values from chemical composition.

\begin{tabular}{|c|c|c|c|c|c|c|}
\hline \multirow[t]{2}{*}{ Cultivar } & Seed & Sprout & Mean & Seed & sprout & Mean \\
\hline & \multicolumn{2}{|c|}{ DCP \% } & \multicolumn{4}{|c|}{ DDM \% } \\
\hline Giza 123 & $7.08^{\mathrm{d}}$ & $7.71^{\mathrm{c}}$ & $7.4 \mathrm{~B}$ & $82.58^{f}$ & $75.95^{j}$ & $79.2 \mathrm{E}$ \\
\hline Giza 126 & $5.84^{g}$ & $8.15^{\mathrm{b}}$ & $6.9 \mathrm{C}$ & $82.66^{\mathrm{e}}$ & $75.94^{\mathrm{j}}$ & $79.3 \mathrm{D}$ \\
\hline Giza 127 & $7.67^{\mathrm{c}}$ & $8.44^{\mathrm{a}}$ & $8.1 \mathrm{~A}$ & $83.38^{\mathrm{d}}$ & $74.93^{\mathrm{k}}$ & $79.1 \mathrm{~F}$ \\
\hline Giza 128 & $4.93^{\mathrm{i}}$ & $6.73^{\mathrm{e}}$ & $5.8 \mathrm{E}$ & $83.56^{\mathrm{c}}$ & $76.64^{\mathrm{i}}$ & $80.1 \mathrm{C}$ \\
\hline Giza 129 & $7.10^{\mathrm{d}}$ & $4.26^{\mathrm{j}}$ & $5.7 \mathrm{~F}$ & $84.55^{\mathrm{a}}$ & $79.15^{\mathrm{h}}$ & $81.8 \mathrm{~A}$ \\
\hline Giza 130 & $6.25^{\mathrm{f}}$ & $5.58^{\mathrm{h}}$ & $5.9 \mathrm{D}$ & $83.66^{\mathrm{b}}$ & $79.96^{\mathrm{g}}$ & $81.7 \mathrm{~B}$ \\
\hline \multirow[t]{2}{*}{ Mean } & $6.5 \mathrm{~B}$ & $6.8 \mathrm{~A}$ & & $83.4 \mathrm{~A}$ & $77.1 \mathrm{~B}$ & \\
\hline & \multicolumn{2}{|c|}{ TDN \% } & \multicolumn{4}{|c|}{ DMI\% } \\
\hline Giza 123 & $90.67^{\mathrm{e}}$ & $84.72^{\mathrm{i}}$ & $87.7 \mathrm{C}$ & $5.59^{\mathrm{d}}$ & $3.20^{\mathrm{i}}$ & 4.4 D \\
\hline Giza 126 & $90.74^{\mathrm{e}}$ & $84.7^{\mathrm{i}}$ & $87.7 \mathrm{C}$ & $5.42^{\mathrm{e}}$ & $3.53^{\mathrm{h}}$ & 4.4 D \\
\hline Giza 127 & $91.39^{\mathrm{d}}$ & $83.8^{\mathrm{j}}$ & $87.5 \mathrm{D}$ & $6.28^{\mathrm{a}}$ & $3.22^{\mathrm{i}}$ & $4.8 \mathrm{C}$ \\
\hline Giza 128 & $91.55^{\mathrm{c}}$ & $85.33^{\mathrm{h}}$ & $88.4 \mathrm{~B}$ & $5.85^{c}$ & $3.62^{\mathrm{h}}$ & $4.7 \mathrm{C}$ \\
\hline Giza 129 & $92.44^{\mathrm{a}}$ & $87.59^{\mathrm{g}}$ & $90.0 \mathrm{~A}$ & $6.21^{\mathrm{ab}}$ & $4.42^{\mathrm{f}}$ & $5.3 \mathrm{~A}$ \\
\hline Giza 130 & $91.64^{\mathrm{b}}$ & $88.32^{\mathrm{f}}$ & $89.9 \mathrm{~A}$ & $6.10^{\mathrm{b}}$ & $4.01^{\mathrm{g}}$ & $5.1 \mathrm{~B}$ \\
\hline Mean & $91.4 \mathrm{~A}$ & $85.7 \mathrm{~B}$ & & $5.9 \mathrm{~A}$ & $3.7 \mathrm{~B}$ & \\
\hline
\end{tabular}

$a, b, c, d, f, g, h, k, l, i, j$, e means with difference latter at the same column are significantly $(p,<0.05)$ different

The effect sprouting produced by different barley cultivarsPredicting energy parameters from chemical composition:

The effect comparison of used some Egyptian barley cultivars for green fodder production in intensive hydroponic system on energy parameters are shown in table (5). The parameters of energy values are predication from chemical composition of Egyptian barley for seeds Giza (128, 127, 130, 129, 126, and 123 ) and its green fodder production observed significantly decreased of $G E, N_{L}, N E_{M}, N E_{g}, D E$ and $M E$ in all several barleys green fodder production compared with its un-sprouted seeds. Except the highest result prediction growth energy (GE)was recorded with seed Giza (129) compared with other barley strains, the values increase from 1.58 to 1.6 (Mcal /Kg DM). Alderman (1985) reported the prediction metabolizable Energy (ME) in the barley green 0.73 fodder was $11.69 \mathrm{MJ} / \mathrm{kg} \mathrm{DM}$ (for ruminants). The means values of seeds were significant decreased compared with sprouting. The means values between strain was significant increase in strain (129 and 130) of DE (Mcal/Lb. of DM). There are different significant means value between seed strains, the best significant results between different strains recorded with Giza (129) of GE, $\mathrm{NE}_{\mathrm{M}}, \mathrm{NE}_{\mathrm{g}}$, DE and ME, The values were $1.59,1.05,0.73,1.80$ and 1.56 , respectivelly

Dung et al., (2010) found that the energy value of the sprouts was also lower than that of the grain on a DM basis, with a gross energy loss of $2 \%$ recorded after comparing the sprouts with the original grain. In addition to this nutrient analysis, they also analyzed the digestibility of the fodder versus original grain in situ. In line with the previously presented material, they found no significant difference in the digestibility and concluded loss of total DM without a significant improvement in digestibility, represents a considerable reduction in total digestible energy. 
Table (5): The effect sprouting produced by different barley cultivars on predicting energy from chemical composition.

\begin{tabular}{|c|c|c|c|c|c|c|c|c|c|}
\hline \multirow[t]{2}{*}{ Cultivar } & Seed & sprout & Mean & Seed & Sprout & Mean & Seed & sprout & Mean \\
\hline & \multicolumn{3}{|c|}{ GE (MJ/Kg DM) } & \multicolumn{2}{|c|}{$\mathrm{NE}_{\mathrm{L}}(\mathrm{Mcal} / \mathrm{Lb}$. of DM $)$} & & \multicolumn{2}{|c|}{$\begin{array}{c}\mathrm{NE}_{\mathrm{M}}(\mathrm{Mcal} / \mathrm{Lb} \text {. of } \\
\mathrm{DM})\end{array}$} & \\
\hline Giza 123 & $1.59^{\mathrm{a}}$ & $1.39^{\mathrm{e}}$ & $1.49^{\mathrm{c}}$ & $0.96^{\mathrm{a}}$ & $0.89^{\mathrm{a}}$ & $0.92^{\mathrm{a}}$ & $1.06^{b}$ & $0.98^{\mathrm{d}}$ & $1.02^{b}$ \\
\hline Giza 126 & $1.52^{\mathrm{c}}$ & $1.49^{\mathrm{c}}$ & $1.50^{\mathrm{c}}$ & $0.96^{\mathrm{a}}$ & $0.89^{\mathrm{a}}$ & $0.92^{\mathrm{a}}$ & $1.06^{\mathrm{b}}$ & $0.98^{\mathrm{d}}$ & $1.02^{\mathrm{b}}$ \\
\hline Giza 127 & $1.6^{\mathrm{e}}$ & $1.40^{\mathrm{c}}$ & $1.50^{\mathrm{c}}$ & $0.96^{\mathrm{a}}$ & $0.88^{\mathrm{a}}$ & $0.92^{\mathrm{a}}$ & $1.07^{\mathrm{ab}}$ & $0.97^{\mathrm{d}}$ & $1.02^{b}$ \\
\hline Giza 128 & $1.44^{\mathrm{d}}$ & $1.45^{\mathrm{d}}$ & $1.44^{\mathrm{d}}$ & $0.97^{\mathrm{a}}$ & $0.90^{\mathrm{a}}$ & $0.92^{\mathrm{a}}$ & $1.07^{\mathrm{ab}}$ & $0.99^{\mathrm{d}}$ & $1.03^{\mathrm{b}}$ \\
\hline Giza 129 & $1.58^{\mathrm{a}}$ & $1.60^{\mathrm{a}}$ & $1.59^{\mathrm{a}}$ & $0.98^{\mathrm{a}}$ & $0.92^{\mathrm{a}}$ & $0.93^{\mathrm{a}}$ & $1.09^{\mathrm{a}}$ & $1.02^{\mathrm{c}}$ & $1.05^{\mathrm{a}}$ \\
\hline Giza 130 & $1.59^{\mathrm{a}}$ & $1.55^{\mathrm{b}}$ & $1.56^{\mathrm{b}}$ & $0.97^{\mathrm{a}}$ & $0.93^{\mathrm{a}}$ & $0.95^{\mathrm{a}}$ & $1.08^{\mathrm{ab}}$ & $1.03^{\mathrm{c}}$ & $1.05^{\mathrm{a}}$ \\
\hline \multirow[t]{2}{*}{ Mean } & $1.55^{\mathrm{a}}$ & $1.48^{\mathrm{b}}$ & & $0.96^{\mathrm{a}}$ & $0.90^{\mathrm{b}}$ & & & & \\
\hline & \multicolumn{2}{|c|}{$\begin{array}{c}\mathrm{NE}_{\mathrm{g}}(\mathrm{Mcal} / \mathrm{Lb} \text {. of } \\
\mathrm{DM})\end{array}$} & & \multicolumn{2}{|c|}{$\begin{array}{c}\text { DE (Mcal /Lb. of } \\
\text { DM) }\end{array}$} & & \multicolumn{2}{|c|}{$\begin{array}{l}\mathrm{ME} \text { (Mcal /Lb. of } \\
\text { DM) }\end{array}$} & \\
\hline Giza 123 & $0.74^{\mathrm{ab}}$ & $0.66^{\mathrm{d}}$ & $0.70^{\mathrm{a}}$ & $1.81^{\mathrm{ab}}$ & $1.69^{\mathrm{e}}$ & $1.75^{b}$ & $1.63^{\mathrm{ab}}$ & $1.51^{\mathrm{c}}$ & $1.57^{c}$ \\
\hline Giza 126 & $0.74^{\mathrm{ab}}$ & $0.66^{\mathrm{d}}$ & $0.70^{\mathrm{a}}$ & $1.82^{\mathrm{a}}$ & $1.69^{\mathrm{e}}$ & $1.76^{\mathrm{b}}$ & $1.63^{\mathrm{ab}}$ & $1.51^{\mathrm{c}}$ & $1.57^{\mathrm{c}}$ \\
\hline Giza 127 & $0.75^{\mathrm{ab}}$ & $0.65^{\mathrm{d}}$ & $0.70^{\mathrm{a}}$ & $1.83^{\mathrm{a}}$ & $1.68^{\mathrm{e}}$ & $1.76^{\mathrm{b}}$ & $1.64^{\mathrm{a}}$ & $1.49^{\mathrm{c}}$ & $1.56^{\mathrm{c}}$ \\
\hline Giza 128 & $0.75^{\mathrm{ab}}$ & $0.67^{\mathrm{cd}}$ & $0.71^{\mathrm{a}}$ & $1.83^{\mathrm{a}}$ & $1.71^{\mathrm{de}}$ & $1.77^{\mathrm{ab}}$ & $1.65^{\mathrm{a}}$ & $1.42^{\mathrm{d}}$ & $1.53^{\mathrm{c}}$ \\
\hline Giza 129 & $0.76 \mathrm{a}$ & $0.70^{\mathrm{bcd}}$ & $0.73^{\mathrm{a}}$ & $1.85^{\mathrm{a}}$ & $1.75^{\mathrm{cd}}$ & $1.80^{\mathrm{a}}$ & $1.66^{\mathrm{a}}$ & $1.65^{\mathrm{a}}$ & $1.65^{\mathrm{a}}$ \\
\hline Giza 130 & $0.75^{\mathrm{ab}}$ & $0.71^{\mathrm{bc}}$ & $0.73^{\mathrm{a}}$ & $1.83^{\mathrm{a}}$ & $1.77^{\mathrm{bc}}$ & $1.80^{\mathrm{a}}$ & $1.65^{\mathrm{a}}$ & $1.58^{\mathrm{b}}$ & $1.61^{\mathrm{b}}$ \\
\hline Mean & $0.75^{\mathrm{a}}$ & $0.67^{\mathrm{b}}$ & & $1.83^{\mathrm{a}}$ & $1.72^{b}$ & & $1.64^{\mathrm{a}}$ & $1.53^{\mathrm{b}}$ & \\
\hline
\end{tabular}

$a, b, c, d, f, g, h, k, l, i, j, e$ means with difference latter at the same column are significantly $(p,<0.05)$ different

\section{Determination digestibility by In-VitroDaisy ${ }^{I I}$ incubator:}

Data about effect comparison of used some Egyptian barley cultivars for seed and its green fodder production in intensive hydroponic system are observed in Table (6) on apparent dry matter and true dry matter digestibility by determination In-Vitro Daisy ${ }^{\mathrm{II}}$ incubator. The values in all several barleys green fodder was significant increase compared with its un-sprouted seeds. The highest values of seed barley were recorded with strain (Giza129) compared with its un-sprouted seed. The values of apparent dry matter digestibility and true dry matter digestibility were significant increased from $87.15 \%, 40.69 \%$ to $93.99 \%$ and $83.15 \%$, respectively. Also, the best significant $(\mathrm{P}<0.05)$ values of data barley for green fodder production recorded with strains (Giza 129) compared with all other strains (Giza 128, 127, 130, 126, and 123). The means values different significant between seeds the best digestible seeds recorded with Giza (129) .Dung et al., (2010) studied the In-Sacco digestibility of sprouted barley fodder visa vs. grain. They found the loss of DM and no difference in In-Sacco digestibility disproved there being an advantage in sprouts rather than the original grain. They found that the initial degradation of the whole sprout was significantly $(\mathrm{P}<0.05)$ higher than for cracked grain after six hours of incubation in the rumen, but from $12-96$ hours there were no significant differences between the whole sprouts and cracked grain. In this respect, Fazaeli et. al., (2012) mentioned that, the DM content of green fodder (GF) was significantly $(\mathrm{P}<0.05)$ reduced by increasing the growing periods from 6 to 7 days. The amount of fresh Gf obtained per $\mathrm{kg}$ of planted barley grain was several times, but this increase was due to the large uptake of water during germination of the seeds, resulted in a sharply reducing of DM percentage in GF. Also, these results were in accordance with those of Bautista (2002) and Morgan et. al., (1992)who reported a significant difference in wet weight (WW) and dry weight (DW) of the hydroponic fodder. Mariana Petkova (2017) reported that the Hydroponic green fodder increased digestibility of the ration. El-Morsy et. al., (2013) stated as sprouting of grains affected the enzyme activity, changes in amino acid profile and increased the total protein which is highly digestible by most animals. 
Table (6): The effect sprouting produced by different barley cultivarsondetermination digestibility by In-VitroDaisy Iincubator: -

\begin{tabular}{lcccccc}
\hline & \multicolumn{2}{c}{ IV-TDMD } & \multicolumn{2}{c}{ IV-ADMD } \\
\hline Cultivar & Seed & Sprouting & Mean & Seed & Sprouting & Mean \\
\hline Giza 123 & $82.59^{\mathrm{h}}$ & $91.29^{\mathrm{d}}$ & $86.9^{\mathrm{d}}$ & $44.08^{\mathrm{h}}$ & $75.27^{\mathrm{c}}$ & $59.7^{\mathrm{b}}$ \\
Giza 126 & $84.64^{\mathrm{g}}$ & $92.19^{\mathrm{c}}$ & $88.4^{\mathrm{c}}$ & $49.98^{\mathrm{g}}$ & $72.62^{\mathrm{e}}$ & $61.3^{\mathrm{a}}$ \\
Giza 127 & $85.93^{\mathrm{f}}$ & $90.92^{\mathrm{d}}$ & $88.4^{\mathrm{c}}$ & $44.84^{\mathrm{h}}$ & $70.00^{\mathrm{f}}$ & $57.4^{\mathrm{d}}$ \\
Giza 128 & $85.86^{\mathrm{f}}$ & $92.63^{\mathrm{c}}$ & $89.2^{\mathrm{b}}$ & $43.05^{\mathrm{i}}$ & $73.70^{\mathrm{d}}$ & $58.4^{\mathrm{c}}$ \\
Giza 129 & $87.15^{\mathrm{e}}$ & $93.99^{\mathrm{a}}$ & $90.6^{\mathrm{a}}$ & $40.69^{\mathrm{j}}$ & $83.15^{\mathrm{a}}$ & $61.9^{\mathrm{a}}$ \\
Giza 130 & $84.57^{\mathrm{g}}$ & $93.31^{\mathrm{b}}$ & $88.9^{\mathrm{b}}$ & $36.46^{\mathrm{k}}$ & $81.26^{\mathrm{b}}$ & $58.9^{\mathrm{c}}$ \\
Mean & $85.1^{\mathrm{b}}$ & $92.4^{\mathrm{a}}$ & & $43.2^{\mathrm{b}}$ & $76.0^{\mathrm{a}}$ & \\
\hline
\end{tabular}

$I V-T D M D=$ in vitro true dry matter digestibility. IV-ADMD = In vitro apparent dry matter digestibility

$a, b, c, d, f, g, h, k, l, i, j$, e means with difference latter at the same column are significantly $(p,<0.05)$ different

\section{Economical study:}

Data in Table (7) illustrated that the effect of different barley cultivars seeds on the cost and profit of forage production. The obtained results indicated that the highest values of economic production and profit were gained by Giza 127 and Giza 129 which gave 39.8 and 38.3LE/m2, 7.1 and 7.0 respectively with constant of other production costs. In this respect, Gebremedhin (2015) reported that the feeding of hydroponically grown maize and barley fodder for growing goats increased the total DM intake, feed conversion efficiency, body weight gain and economically valid. Also, agreement results were displayed by (Hassan and Mona 2013) in sprouted maize fodder fed to desert goats and reported, environmentally friendly as well as reduced cost of feeding, while, Naik et al. (2013) revealed increase in milk yield by 0.52.5litres/animal/day and earned net profit of Rs. 25-50 due to feeding of hydroponic fodder to their dairy animals. Bradley and Marulanda (2000) reported that hydroponic green fodder production technique requires only about $10-20 \%$ of the water needed to produce the same amount of crop in soil culture.

Table (7): The effect of sprouting produced by different barley cultivars on the average of cost and profit of production: -

\begin{tabular}{lllllll}
\hline Treatment & $\begin{array}{l}\text { Seeds } \\
\text { weight } \\
\mathrm{kg} / \mathrm{m}^{2}\end{array}$ & $\begin{array}{l}\text { Cost of seed } \\
(\mathrm{Kg}=3 \mathrm{LE})\end{array}$ & $\begin{array}{l}\text { Fresh weight } \\
\mathrm{Kg} / \mathrm{m}^{2}\end{array}$ & $\begin{array}{l}\text { Production } \\
(\mathrm{Kg}=1.25 \mathrm{LE}) \\
\mathrm{LE} / \mathrm{m}^{2}\end{array}$ & $\begin{array}{l}\text { The profit } \\
\mathrm{LE} / \mathrm{m}^{2}\end{array}$ & Biomass \\
\hline Giza 123 & $10 \mathrm{a}$ & $30 \mathrm{a}$ & $51.6 \mathrm{~d}$ & $64.5 \mathrm{~d}$ & $21.6 \mathrm{~d}$ & $5.2 \mathrm{~d}$ \\
Giza 126 & $10 \mathrm{a}$ & $30 \mathrm{a}$ & $50.9 \mathrm{~d}$ & $63.6 \mathrm{~d}$ & $20.9 \mathrm{~d}$ & $5.1 \mathrm{~d}$ \\
Giza 127 & $10 \mathrm{a}$ & $30 \mathrm{a}$ & $69.8 \mathrm{a}$ & $87.3 \mathrm{a}$ & $39.8 \mathrm{a}$ & $7.1 \mathrm{a}$ \\
Giza 128 & $10 \mathrm{a}$ & $30 \mathrm{a}$ & $60.9 \mathrm{~b}$ & $76.1 \mathrm{~b}$ & $30.9 \mathrm{~b}$ & $6.1 \mathrm{~b}$ \\
Giza 129 & $10 \mathrm{a}$ & $30 \mathrm{a}$ & $68.3 \mathrm{a}$ & $85.4 \mathrm{a}$ & $38.3 \mathrm{a}$ & $7.0 \mathrm{a}$ \\
Giza 130 & $10 \mathrm{a}$ & $30 \mathrm{a}$ & $56.0 \mathrm{c}$ & $70.0 \mathrm{c}$ & $26.0 \mathrm{c}$ & $5.6 \mathrm{c}$ \\
\hline
\end{tabular}

$* a, b, c, d$ means with difference latter at the same column are significantly $(p,<0.05)$ differentSimilar letters indicate non-significant at 0.05 levels. 


\section{CONCLUSION}

Climate change impacts on agriculture system take in high consider through study the efficiency of intensive hydroponic system in producing green fodder. The sprouting of barley under intensive hydroponic system recorded into a high quality, highly nutritious, disease free animal food. This process takes place in a very versatile and intensive hydroponic growing unit, where only water and nutrients are used to produce a grass and root combination that is very highest values in nutrients, in physical characteristics, indigestibility analysis, high in protein and production costs. The best result recorded with sprouted barley yield using Egyptian barley Giza 127 and Giza 129 barley cultivar may be could use in animal's diets as hydroponic green forage in short period ( 8 days -3.5 production cycles /month) any time from year .Barley sprouts is considered the best choice that can be used for production of hydroponic green fodder with less water consumption; especially seeds of this crop are mostly available in the market at lower price than others which reduce the cost of hydroponic fodder production

\section{REFERENCES}

Al-Ajmi, A.; A. Salih; I. KadhimandY. Othman (2009).Yield and water use efficiency of barley fodder produced under hydroponic system in GCC countries using tertiary treated sewage effluents. Journal of Phytology, 1(5): 342-348.

Alderman, G. (1985). Prediction of the energy value of compound feeds. In: W. Haresign W. and D. J. A. Cole (Eds.) Recent Advances in Animal Nutrition: 285.

Al-Hashmi, M. M. (2008). Hydroponic green fodder production in the Arabian Gulf Region. MSc. Thesis, Faculty of Graduate Studies, Arabian Gulf University, Bahrain.

Al-Karaki, G. N. (2010). Hydroponic green fodder: alternative method for saving water in dry areas. In Proceedings of the "Second Agricultural Meeting on Sustainable Improvement of Agricultural and Animal Production and Saving Water Use. September 2010, Sultanate of Oman.

ANKOM(2005). Procedures for NDF, ADF and ADL Analysis, URL: http://www.ankom.com.

AOAC (2000): Official Methods of Analysis of the Association of Official Analytical Chemists, 17th ed. Gaithersburg, Maryland, USA.

Bautista, S.H. (2002). Producción de forrajeverdehidropónico de trigoTriticumaestivum L. para el mantenimiento de conejos criollos Oryctolagus cuniculus. Thesis. Universidad Autónoma de Guerrero (UAG) Chilpancingo, Guerrero, México.

Bradley,P. and C., Marulanda(2000). "Simplified hydroponics to reduce global hunger," Acta Horticulture, vol. 554, pp. 289- 295.

Cader and Bill. (2002). Simple Shed Company, Morayfield, Queensland, Australia, scholarship report:-p.9.

Chavan, J.K., \& Kadam, S.S. (1989). Nutritional improvement of cereals by fermentation and technology. Critical Reviews in Food Science and Nutrition, 28, (5) 349.

Chung, T. Y.; E. N., Nwokolo and J. S.,Sim(1989). Compositional and digestibility changes in sprouted barley and canola seeds. Plant Foods for Human Nutrition. 39: 267-278.

Cuddeford, D. (1989). Hydroponic Grass. In Practice 11(5): 211-214.

Dung, D. D.;I.R.,Goodwin and J. V.,Nolan (2010). Nutrient content and In-Sacco digestibility of barley grain and sprouted barley. Journal of Animal and Veterinary Advances, 9 (19), 2485-2492.

El-Morsy A. T.; M. Abul-Soud and M. S. A., Emam(2013). Localized hydroponic green forage technology as a climate change adaptation under Egyptian conditions. Research Journal of Agriculture and Biological Sciences, 9(6): 341-350. 


\section{Emam et al.}

Fazaeli, H.; H. A., Golmohammadi; S.N.,Tabatabayee and M.,Asghari- Tabrizi (2012). Productivity and nutritive value of barley green fodder yield in hydroponic system. World Applied Sciences Journal 16(4). 531-539.

Gebremedhin, W. K. (2015).Nutritional benefit and economic value of feeding hydroponically grown maize and barley fodder for Konkan Kanyal goats. Journal of Agriculture and Veterinary Science. IOSR Journal of Agriculture and Veterinary Science (IOSR-JAVS), Vol. 8, Issue 7 Ver. II (July. 2015): 24-30.

Goeser, J. P. and Combs, D. K. (2009). An alternative method to assess 24-h ruminal in vitro neutral detergent fiber digestibility. J. Dairy Sci. 92:3833-3841

Goldman, A.; A. Genizi; A. Yulzari and N.G. Seligman (1987).Improving the reliability of the two-stage in vitro assay for ruminant feed digestibility by calibration against in vivo data from a wide range of sources. Animal feed since and technology.volume 18, issue 3 page 233-245.

Hassan, G.H. and M.H., Mona (2013). Sprouted Zea Mays on date palm leaves and potatoes peel waste mixture and its effects onperformance of desert goats under dry season in Sinai. Desert Research center, Mataria, Cairo, Egypt.

Jensen, H. and A. Malter(1995). Protected agriculture a global review. World bank technical paper number 253. $156 \mathrm{p}$.

Kanauchi O.; T., Nakamura; K.,Agata; K., Mitsuyama and T., Iwanaga(1998). Effects of germinated barley foodstuff on dextrin sulfate sodium-induced colitis in rats. J. Gastroenterol. 33(2):179-88.

Kent-Jons, D.W. and Amos, A.J. (1967). Modern cereal chemistry. 6th Ed., food trade press Ltd., London.

Lattimer, J. M.; Cooper, S. R.; Freeman, D. W. and Lalman, D. L.;(2007). Effect of yeast culture on in vitro fermentation of a high-concentrate. J. Anim. Sci. 2007. 85:2484-2491

MAFF. (1975). Ministry of Agriculture, Fisheries and Food. Energy allowances andfeeding systems for ruminants. Tech. Bulletin., 33, London, HM 50.

Mansbridge, R.J. and B.J., Gooch(1985). A nutritional assessment of hydroponically grown barley for ruminants. Animal Production, 40: 569-570.

Mariana Petkova (2017).Hydroponic Green Fodder-Nutritional Potential Found in Bulgaria. EC Nutrition 10.1 (2017): 15-17.

Mayer, A.M., and A. Poljakoff-Mayber. 1975. The Germination Seeds. 2nd ed. Pergamon Press, New York. 192.

Mertens D.R. (2002). Gravimetric determination of amylase-treated neutral detergent fiber in feeds with refluxing in beakers or crucibles: collaborative study. J AOAC ;85(6):1217-40.

Morgan, J.; R.R.,HunterandR.,O’Haire(1992).Limiting factors in hydroponic barley grass production. Proceedings of the $8^{\text {th }}$ International Congress on Soilless Culture, Hunter's Rest, 2-9 October 1992, 241261.

Mukhopad, Y. (1994). Cultivating green forage and vegetables in the Buryat Republic. MezhdunarodnyiSel'skokhozyaistvennyiZhurnal, 6: 51-52.

N.R.C. (2001). Nutrient Requirement of dairy cattle ( $7^{\text {th }}$ Rev. Ed). National Academy Pres. Washington, D.C.

Naik, P.K.; S.P. Gaikwad; M.J. Gupta; R.B. Dhuri; G.M. Ghumal and N.P., Singh (2013).Low cost devices for hydroponics fodder production, I.C.A.R. Research complex for Goa, old Goa-India.

Peer, D.J. and S., Leeson(1985a). Feeding value of hydroponically sprouted barley for poultry and pigs. Animal Feed Science and Technology, 13: 183-190. Press, Ames, Iowa, USA, 225-330

Peer, D.J. and S. Leeson, 1985b. Nutrient content of hydroponically sprouted barley. Animal Feed Science and Technology, 13: 191-202.

Rajendra, P.; J.P.,Seghal; B.C.,Patnayak and R.K., Beniwal(1998). Utilization of artificially grown barley fodder by sheep. Indian Journal of Small Ruminants, 4(2): 63-68.Republic. MezhdunarodnyiSel'skokhozyaistvennyiZhurnal, 6(1): 51-52. 
Shtaya, I. (2004). Performance of Awassi ewes fed barley green fodder. Master thesis. AnNajah National University.

Sneath, R. and F., McIntosh(2003). Review of hydroponic fodder production for beef cattle. Department of Primary Industries: Queensland Australia 84. McKeehen, pp: 54.

Snedicor, G.W. and W.G., Cochran(1981). "Statistical Methods" $7^{\text {th }}$ ed., Iowa State Univ.,

Snow, A.M., A.E. Ghaly and A. Snow, 2008. A Comparative Assessment of Hydroponically Grown Cereal Crops for the Purification of Aquaculture Wastewater and the Production of Fish Feed. American Journal of Agricultural and Biological Sciences, 3(1): 364-378.

Stern M. D.; Alex Bach, and Sergio Calsamiglia (1997). Alternative Techniques for Measuring Nutrient Digestion in Ruminants. J. Anim. Sci. 1997. 75:2256-2276.

Tilley J.M. A and R.A. A. Terry (1963). Two stage technique for the in vitro digestion of forage crops. J. Br. Grassl Soc. 18:104-111.

Trubey, C.R.; C.L.,Rhyckerd; C.H. Noller; D.R., Ford and J.R., George(1969). Effect of light, culture solution and growth period on growth and chemical composition of hydroponically produced oat seedlings. Agron. J., 61: 663-665.

Tudor, G.; T. Darcy; P., Smith and F., Shallcross(2003). The intake and live weight change of drought master steers fed hydroponically grown, young sprouted barley fodder, Department of Agriculture Western Australia.

Van Soest P.; J., Robertson and B., A., Lewis (1991). Symposium: Carbohydrate methodology, metabolism and nutritional implications in dairy cattle. methods for dietary fiber, neutral detergent fiber and nonstarch polysaccharides in relation to animal nutrition. J. Dairy Sci. 74: 3583-3597.

Wilman, D. and Desogan, A. (2000). A comparison of filter bag methods with conventional tube methods of determining the in vitro digestibility of forages. Animal feed since and technology. Volume 18, Issue 1-2, P. 33-47.

Yılmaz, N. (2007). Arpa. TarımsalEkonomiAraştırmaEnstitusu T. E. A. E Bakış, 9 (2): 1-4. 
تقدير بعض من اصناق الثعير المصرى المزروع كاعلف اخضر بنظام الزراعة المائية والتبؤ بالقيم الهضمية In-vitro Daisy II incubator بواسطة طريز

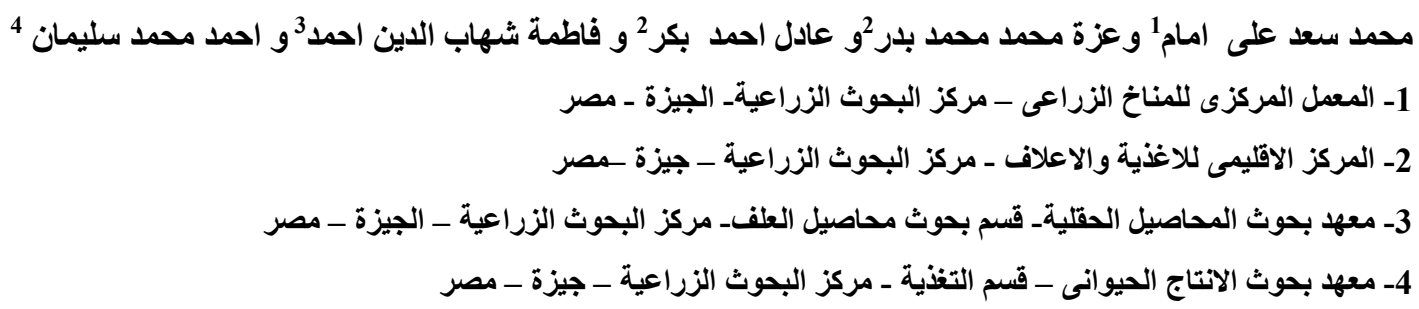

أخذت الزر اعة تحت الظروف المصرية المزيد من الاهتمام في العقد الماضي. وتم إجر اء التجربة تحت النظام المائي المكثف وتم تكرارها

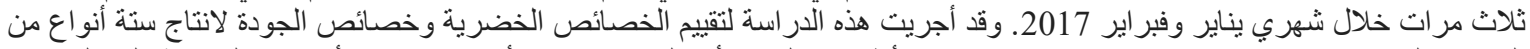

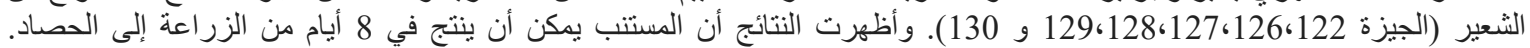

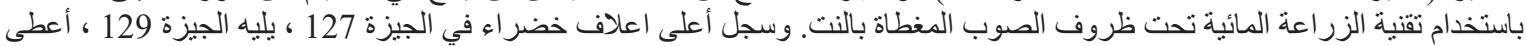

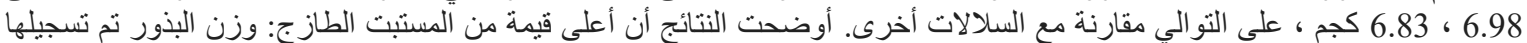
بشكل ملحوظ فى الجيزة 127 تليها الجيزة 129 مقارنة التهان بالأصناف الأربعة الأخرى.

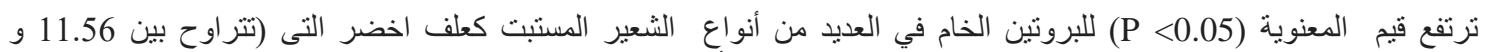

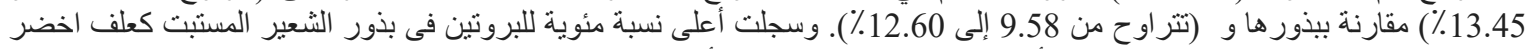

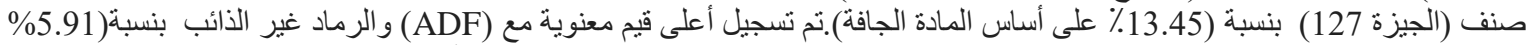

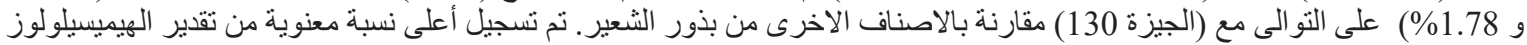

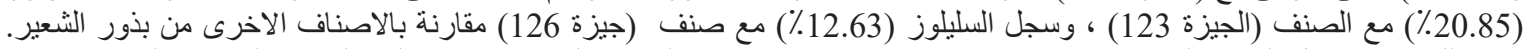

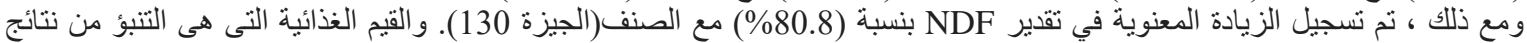

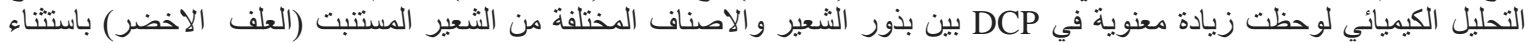

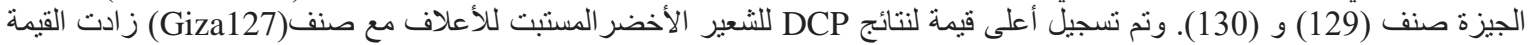

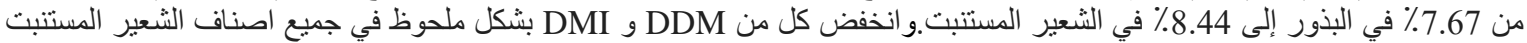

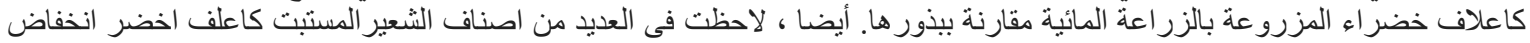

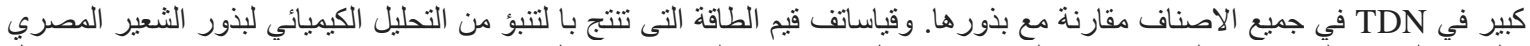

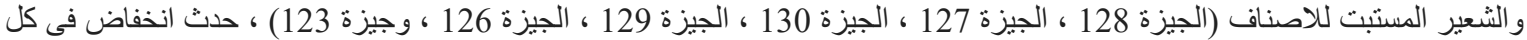

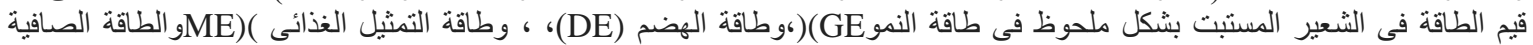

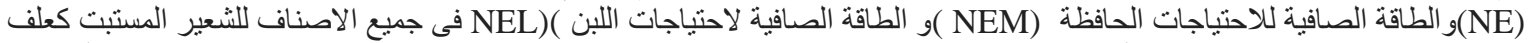

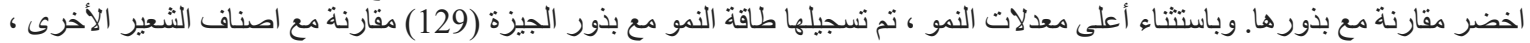

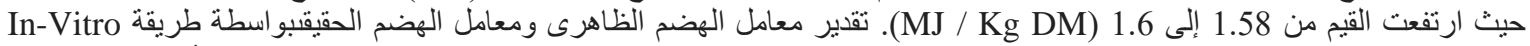
كaisyII

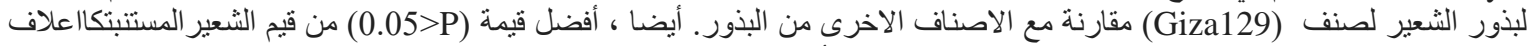

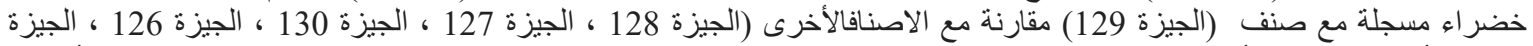

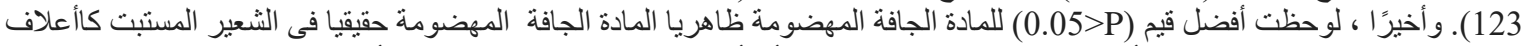

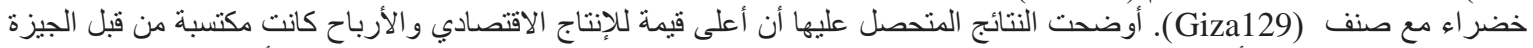

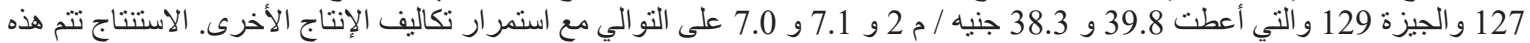

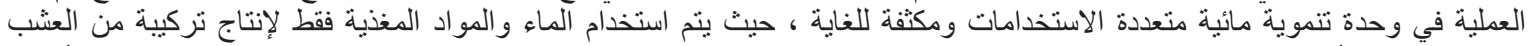

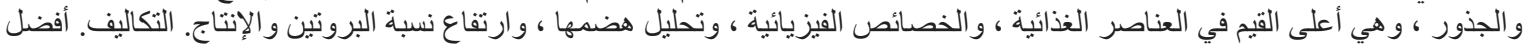

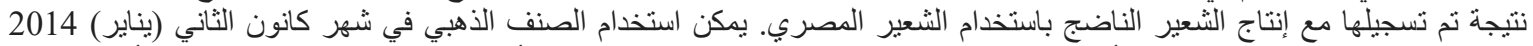

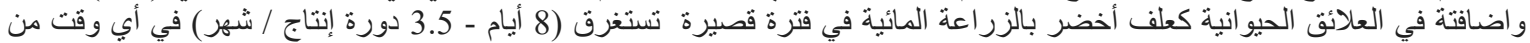

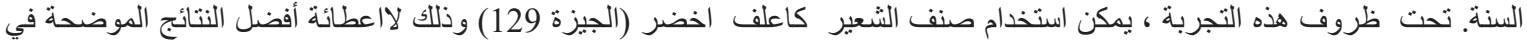
التنبؤ بالنظام الغذائي للحيو انات المجترة و هذه الأعلاف الخضر اء المستبتة هي مناسبة للاستخدام في جميع أنواع وفئات الحيوانات. 